Article

\title{
Cyclodextrin Rotaxanes of Pt Complexes and Their Conversion to Pt Nanoparticles
}

\author{
Yuji Suzaki ${ }^{1}$, Yuhei Fujii ${ }^{1}$ and Kohtaro Osakada ${ }^{1,2, *(0)}$ \\ 1 Laboratory for Chemistry and Life Science, Tokyo Institute of Technology, 4259 Nagatsuta, \\ Yokohama 226-8503, Japan; ysuzaki@gmail.com (Y.S.); funky.southern.ymt@gmail.com (Y.F.) \\ 2 National Institute of Advanced Industrial Science and Technology (AIST), Tsukuba Central 5, 1-1-1 Higashi, \\ Tsukuba, Ibaraki 305-8565, Japan \\ * Correspondence: kosakada@res.titech.ac.jp; Tel.: +81-45-924-5224
}

Received: 12 November 2020; Accepted: 23 November 2020; Published: 29 November 2020

\begin{abstract}
The cationic $\mathrm{Pt}$ complex $\left(\mathrm{Pt}\left(\mathrm{NC}_{6} \mathrm{H}_{4}-\mathrm{C}_{6} \mathrm{H}_{4} \mathrm{~N}-\left(\mathrm{CH}_{2}\right)_{10}-\mathrm{O}\left(\mathrm{C}_{6} \mathrm{H}_{3}-3,5-(\mathrm{OMe})_{2}\right)(\mathrm{MeN}-\right.\right.$ $\left.\left.\left(\mathrm{CH}_{2} \mathrm{CH}_{2} \mathrm{NMe}_{2}\right)_{2}\right)\right)^{+}$was prepared by the reaction of alkylbipyridinium ligand with a nitrateplatinum(II) complex. Mixing the complex and $\alpha$ - and $\beta$-cyclodextrins in aqueous media produced the corresponding [2] rotaxanes with 1:1 stoichiometry. $\gamma$-Cyclodextrin and the Pt complex formed a rotaxane having components in a 1:1 or 2:1 molar ratio. The results of mass and nuclear magnetic resonance (NMR) measurements confirmed the rotaxane structures of the Pt complexes. Transmission electron microscopy (TEM) and atomic force microscope (AFM) analyses revealed the formation of micelles or vesicles. The addition of $\mathrm{NaBH}_{4}$ to the rotaxanes in aqueous media formed Pt nanoparticles with diameters of 1.3-2.8 nm, as characterized by TEM. The aggregated size of the nanoparticles formed from the rotaxane did not change even at $70^{\circ} \mathrm{C}$, and they showed higher thermal stability than those obtained from the reduction of the cyclodextrin-free $\mathrm{Pt}$ complex.
\end{abstract}

Keywords: platinum; cyclodextrin; rotaxane; nanoparticles

\section{Introduction}

Pt nanoparticles have been investigated because of their usability in catalysis, fuel cell materials, and sensing materials [1]. A common preparation procedure of Pt nanoparticles involves the preparation of precursors from $\mathrm{H}_{2} \mathrm{PtCl}_{6}$ and template compounds, such as surfactants and polymers dispersed in aqueous media. The subsequent reduction of the $\mathrm{Pt}(\mathrm{IV})$ species results in the deposition of the $\mathrm{Pt}$ nanoparticles under mild conditions. Surfactants have a dual role in the process: coordination with the Pt-containing precursors to keep their colloidal aggregation in the aqueous media, and protection of the formed nanoparticles by preventing their further growth. A typical preparation procedure was reported as follows. The addition of an aqueous solution of $\mathrm{H}_{2} \mathrm{PtCl}_{6}$ to an isooctane solution of sodium bis(2-ethylhexyl) sulfosuccinate (AOT) formed a colloidal suspension containing Pt salt. An $\mathrm{NaBH}_{4}$ reduction of the precursor suspension at $4{ }^{\circ} \mathrm{C}$ yielded Pt nanoparticles with an average diameter of $13 \mathrm{~nm}$ [2]. Tetradecyltrimethylammonium bromide (TTAB) and sodium citrate were also used as templates for the synthesis of the Pt nanoparticles [3,4]. Polymers such as polyvinylpyrrolidone (PVP) [5,6] and poly(acrylic acid) (PA) [7] function as templates to stabilize metal nanoparticles effectively. Natural polymers, such as silk, were reported to function as the template in the $\mathrm{Pt}$ nanoparticle formation [8]. The reduction of the $\mathrm{Pt}(\mathrm{IV})$ precursors with diol and alcohol at elevated temperatures also produced the Pt nanoparticles [9]. Typically, Toste et al. heated an ethylene glycol solution of $\mathrm{NaOH}$ and $\mathrm{H}_{2} \mathrm{PtCl}_{6}$ at $160{ }^{\circ} \mathrm{C}$, and neutralized the mixture by using $\mathrm{HCl}$ [10]. Dispersing the resulting mixture in an ethanol solution of PVP caused the formation of Pt nanoparticles with a diameter of $1.5 \mathrm{~nm}$. Conversely, the sequential addition of the aqueous $\mathrm{H}_{2} \mathrm{PtCl}_{6}$ solution and $\mathrm{PVP}$ to 
methanol, followed by heating the mixture, caused the formation of Pt particles with a diameter of $2.9 \mathrm{~nm}$. The Pt particles supported by silica were used as the catalyst for the selective synthesis of heterocyclic compounds.

Rotaxanes are molecules consisting of more than one component, i.e., macrocyclic and linear compounds, with the former encircling the latter. Major research interest in rotaxanes pertains to their applicability as molecular machines, molecular devices [11-20], and supramolecular catalysts [21-25]. Cyclodextrins have tube-like molecular structures and form rotaxanes with linear-shaped organic and polymer molecules. Cyclodextrins and transition-metal complexes having alkyl or alkylene ligands have been investigated for several decades [26-30]. Studies on the cyclodextrin rotaxanes of hydrophobic organic polymers have revealed their aggregation in the solid state caused by the intermolecular interaction of cyclodextrin components [31-40]. Previously, we prepared pseudo-rotaxanes composed of 4-alkyl-4,4'-bipyridinium, with a bulky 3,5-dimethylphenyl end (linear component) and cyclodextrins (macrocyclic component) [41-44]. The addition of Pd and Pt complexes to the mixture of cyclodextrins and $\omega$-(3,5-dimethylphenyl)-4-alkyl-4,4'-bipyridine yielded rotaxanes containing the metal complex of the bipyridinium ligand as the axle component. The rotaxanes and pseudorotaxanes form micelles in aqueous media because of their tendency to aggregate. Our goal is to use the aggregated rotaxanes as a precursor to metal nanoparticles. The reduction of micellar aggregates of transition metal complexes has been reported as an efficient procedure for preparing metal nanoparticles under mild conditions. Lee reported that a mixture of an organic surfactant and $\mathrm{H}_{2} \mathrm{PtCl}_{6}$ was reduced by dodecanol to form $\mathrm{Pt}$ nanoparticles with a diameter of $1.7 \pm 0.5 \mathrm{~nm}$ [45]. The reduction of a mixture of $\mathrm{HAuCl}_{4}$ and a cationic surfactant dispersed in water was found to produce Au nanoparticles with a diameter of $1.9 \pm 0.3 \mathrm{~nm}$ [46]. Chaudhary employed metallomicelles of a $\mathrm{Pd}(\mathrm{II})$ complex with dodecylamine ligands as the precursor to Pd nanoparticles, and obtained a product with a diameter of 3.4-4.0 nm [47].

Scheme 1 outlines the formation of Pt nanoparticles in this work. Mixing cyclodextrin, a Pt(II) complex with $N$-alkylbipyridinium ligand (A), and nitrate-platinum complex (B) in aqueous media forms pseudorotaxane of cyclodextrin and the dissociated ligand (C), as well as Pt-containing rotaxane (D). Both Pt complexes (A) and (D) are aggregated in micellar form in aqueous media, and they are converted into Pt nanoparticles upon reduction. We planned to use several mixtures of (A) and excess amounts of (B) and cyclodextrins as a precursor to Pt nanoparticles. Different amounts of the starting compounds shift the equilibrium to depress the formation of the CD-free complex (A) and pseudorotaxane $(\mathrm{C})$. Thus, the reduction of the mixture would yield Pt nanoparticles from the rotaxane (D) rather than a CD-free complex (A). The reduction of complex (B) also forms Pt, but in bulk, because of the dissolution of the complex in aqueous media. In this paper, we report the conversion of a $\mathrm{Pt}$ complex with a rotaxane structure into $\mathrm{Pt}$ nanoparticles by $\mathrm{NaBH}_{4}$ reduction, as well as the characterization of the rotaxanes in micellar aggregates and metal nanoparticles.
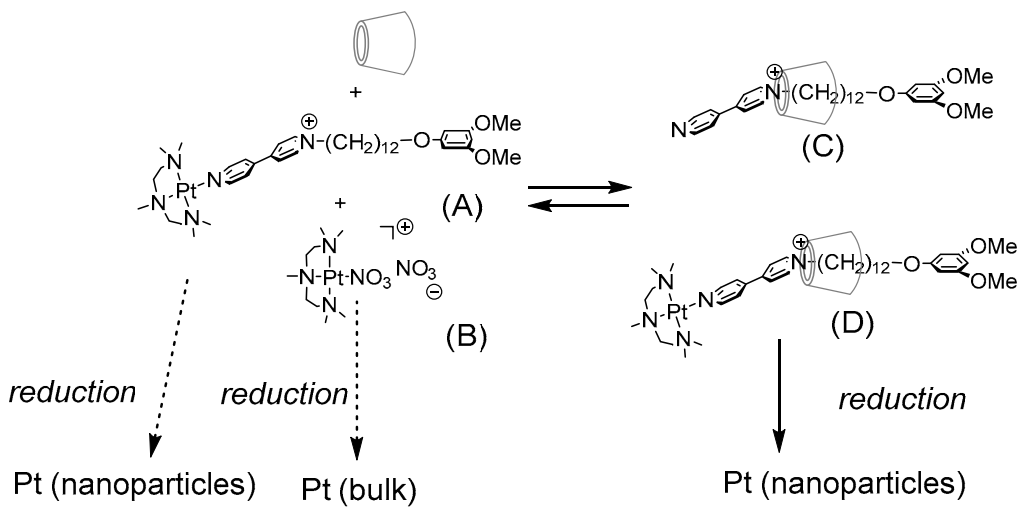

Scheme 1. Formation of Pt-containing rotaxanes and Pt nanoparticles in this study. 


\section{Results and Discussion}

\subsection{Preparation and Characterization of the Cyclodextrin Rotaxanes of the Pt Complex}

A reaction of $4,4^{\prime}$-bipyridinium derivative having a $\omega$-(3,5-methoxyphenoxy)dodecyl substituent at a pyridine nitrogen $\left(\mathrm{NC}_{6} \mathrm{H}_{4}-\mathrm{C}_{6} \mathrm{H}_{4} \mathrm{~N}-\left(\mathrm{CH}_{2}\right)_{12}-\mathrm{O}\left(\mathrm{C}_{6} \mathrm{H}_{3}-3,5-(\mathrm{OMe})_{2}\right)^{+}\left([1]^{+}\right)\right.$with a Pt complex having a 1,1,4,7,7-pentamethyl-1,4,7-triaza-heptane ( $\mathrm{Me}_{5}$ dien) ligand $\left(\mathrm{Pt}\left(\mathrm{NO}_{3}\right)\left(\mathrm{Me}_{5} \text { dien }\right)\right)^{+}\left([2]^{+}\right)$in the presence of $\mathrm{AgNO}_{3}$ affords a complex containing the amphiphilic ligand $\left(\mathrm{Pt}\left(\mathrm{Me}_{5}\right.\right.$ dien $\left.)(\mathbf{1})\right]\left(\mathrm{NO}_{3}\right)_{3}\left([3]\left(\mathrm{NO}_{3}\right)\right)$. The addition of $\alpha$-cyclodextrin to a mixture of [3] $\left(\mathrm{NO}_{3}\right)_{3}$ and [2] $\left(\mathrm{NO}_{3}\right)$ (molar ratio of 2:1:2), followed by heating the resulting aqueous solution for $102 \mathrm{~h}$, caused the formation of [2]rotaxane $((3)(\alpha-\mathrm{CD})]\left(\mathrm{NO}_{3}\right)_{3}$ as shown in Scheme 2(i). ${ }^{1} \mathrm{H}$-nuclear magnetic resonance (NMR) spectrum of the reaction mixture suggested the complete complexation of the bipyridinium ligand to the Pt center and the absence of bare alkylbipyridinium or its organic pseudorotaxane with $\alpha-C D\left([1]^{+}\right.$and $\left.[(\mathbf{1})(\alpha-C D)]^{+}\right)$. The reaction without the addition of extra [2] was very slow and did not reach completion even after prolonged heating. An excess amount of $[2]^{+}$in the mixture enhanced the formation of $[(3)(\alpha-\mathrm{CD})]\left(\mathrm{NO}_{3}\right)_{3}$ via the reversible dissociation and association of the bipyridinium ligand. Complexes $[3]^{3+}$ and [2] ${ }^{+}$undergo a mutual exchange of the bipyridinium ligand, and rapidly form a rotaxane via the dissociation of the ligand of $[3]^{3+}$, formation of pseudorotaxane $[(\mathbf{1})(\alpha-C D)]+$, and re-coordination of the pseudorotaxane to the Pt center of $[2]^{+}$.

The individual reaction of $\beta$-cyclodextrin and $\gamma$-cyclodextrin with a mixture of $[3]\left(\mathrm{NO}_{3}\right)_{3}$ and [2] $\left(\mathrm{NO}_{3}\right.$ ) (molar ratio: 2:1:1 for the former and 1:2:4 for the latter) afforded the respective cationic rotaxanes $[(3)(\beta-\mathrm{CD})]\left(\mathrm{NO}_{3}\right)_{3}$ and $\left[(3)_{2}(\gamma-\mathrm{CD})_{2}\right]\left(\mathrm{NO}_{3}\right)_{6}$ within $5 \mathrm{~min}$ (r.t.) (Scheme 2(ii), (iii)). The rapid formation of the rotaxanes is ascribed to the large ring size of $\beta$ - and $\gamma-C D$, which enables slipping synthesis of the rotaxanes. Isolation of the resulting rotaxanes was not successful because of the reversible formation and degradation of the rotaxanes in the solution. We conducted a titration study of the formation of $[(3)(\beta-\mathrm{CD})]\left(\mathrm{NO}_{3}\right)_{3}$ and $\left[(3)_{2}(\gamma-\mathrm{CD})_{2}\right]\left(\mathrm{NO}_{3}\right)_{6}$ by using ${ }^{1} \mathrm{H}-\mathrm{NMR}$ spectroscopy in order to obtain further insight of the reaction.

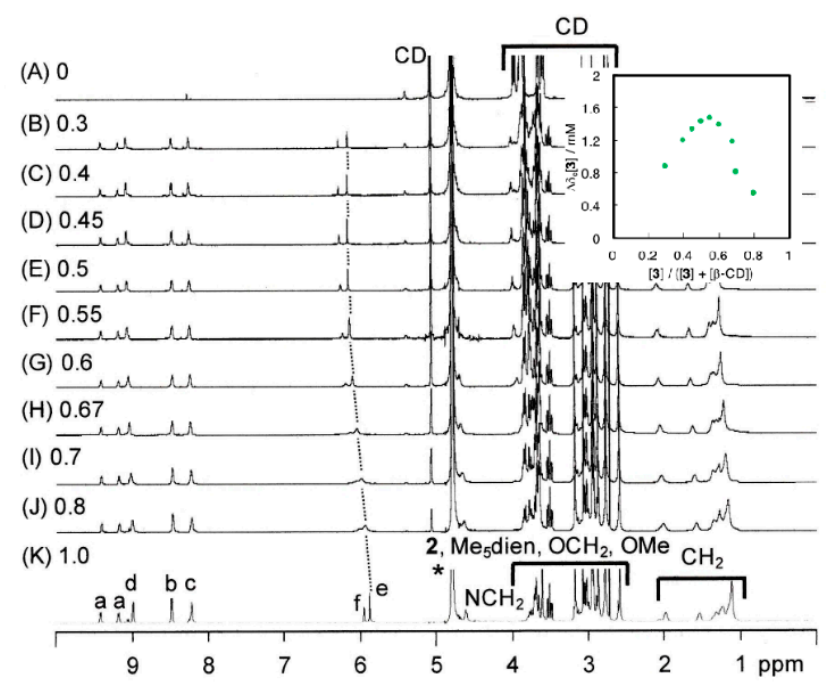

Figure 1. ${ }^{1} \mathrm{H}$-nuclear magnetic resonance (NMR) spectra of the mixtures of $[3]^{3+}$ and $\beta$-cyclodextrin. $\left(\mathrm{D}_{2} \mathrm{O}\right.$, r.t., $\left.500 \mathrm{MHz}\right) .[3] /([3]+[\beta-\mathrm{CD}])=(\mathbf{A}) 0,(\mathbf{B}) 0.3,(\mathbf{C}) 0.4,(\mathbf{D}) 0.45,(\mathbf{E}) 0.5,(\mathbf{F}) 0.55,(\mathbf{G}) 0.6,(\mathbf{H}) 0.67$, (I) 0.7, (J) 0.8, (K) 1.0. Signals a-f are assigned to the hydrogens of complex 3, in Scheme 2. A signal with asterisk is due to HDO in the solvent. Job's plots based on the positions of the signal (e) are shown in the inset. 


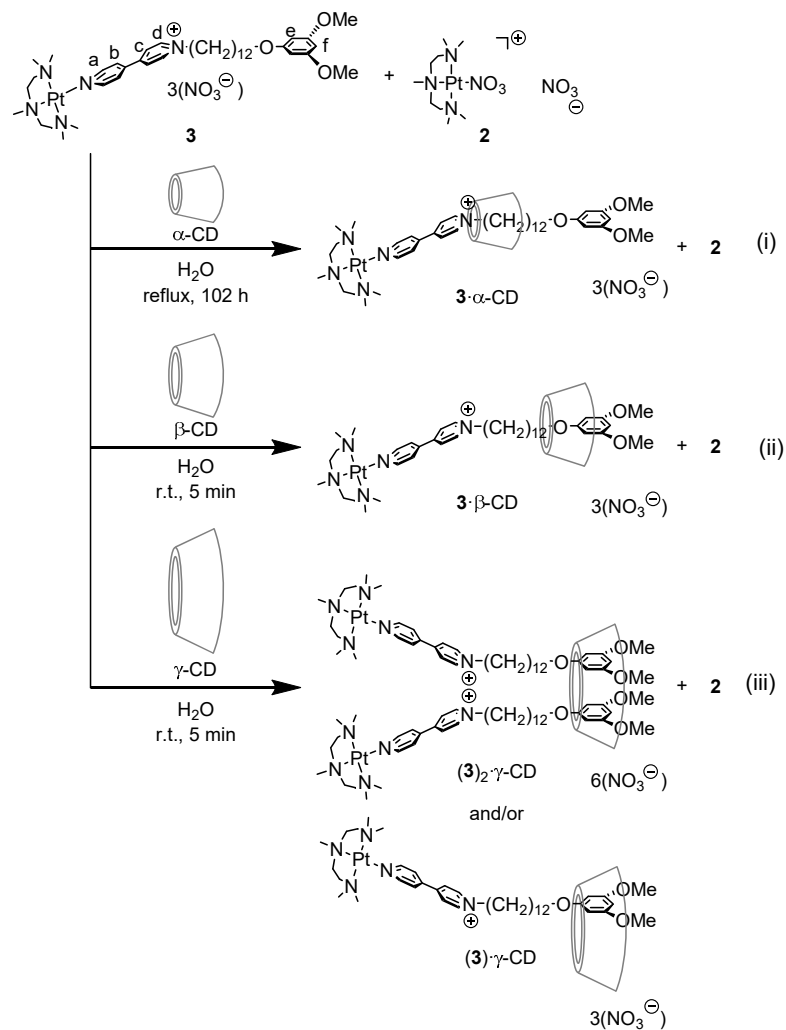

Scheme 2. Preparation of cyclodextrin rotaxanes. Symbols a-f in complex 3 denote aromatic hydrogens at the respective positions. They correspond to the NMR spectra in Figure $1(\mathrm{~K})$ and Figure 2(N). (i)-(iii) show the rotaxane or pseudorotaxane obtained from $\alpha_{-}, \beta-$, and $\gamma$-cyclodextrins, respectively.

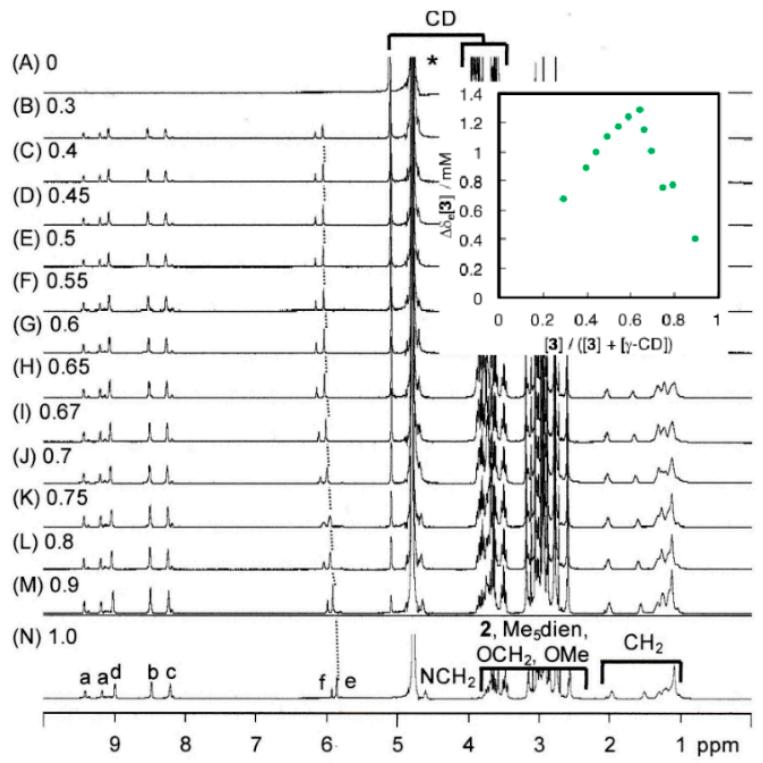

Figure 2. ${ }^{1} \mathrm{H}-\mathrm{NMR}$ spectra of mixtures of $[3]^{3+}$ and $\gamma$-cyclodextrin. $\left(\mathrm{D}_{2} \mathrm{O}\right.$, r.t., $\left.500 \mathrm{MHz}\right)$. $[3] /([3]+[\gamma-C D])=(\mathbf{A}) 0,(\mathbf{B})$ 0.3, (C) 0.4, (D) 0.45, (E) 0.5, (F) 0.55, (G) 0.6, (H) 0.65, (I) 0.67, (J) 0.7, (K) 0.75, (L) 0.8, (M) 0.9, (N) 1.0. Signals a-f are assigned to the hydrogens of complex 3, in Scheme 2. A signal with asterisk is due to HDO in the solvent. Job's plots based on the positions of the signal (e) are shown in the inset. 
Figure 1 presents the results of titration using $\beta$-cyclodextrin. The aromatic hydrogen signals $(e, f)$ of $[3]^{3+}(K)$ are shifted to lower magnetic field positions upon the increase of $\beta$-cyclodextrin concentration (the total concentration of $[3]^{3+}$ and $\beta-C D$ are $10.0 \mathrm{mM}$ ). Job's plots based on the change of the ${ }^{1} \mathrm{H}-\mathrm{NMR}$ signal due to aromatic hydrogen e suggest the aggregation of the complex and $\beta-C D$ close to 1:1 stoichiometry (inset of Figure 1).

Complex $[3] \mathrm{NO}_{3}$ and $\gamma$-cyclodextrin could form not only [3]rotaxane $\left[(3)_{2}(\gamma-\mathrm{CD})\right]^{6+}$ via a 1:2 aggregation of the macrocyclic and axle components, but also [2] rotaxane $[(3)(\gamma-C D)]^{3+}$ by a $1: 1$ aggregation in the solution. We conducted titration of the two components in the NMR samples, whose results are shown in Figure 2. The ${ }^{1} \mathrm{H}$ NMR signals of complex [3] $\mathrm{NO}_{3}$, particularly those of the aromatic hydrogens, shift towards lower magnetic field positions. Job's plots of the signal positions show a maximum close to 0.65 , which is consistent with the 1:2 aggregation (inset of Figure 2). Thus, complex [3] $]^{3+}$ forms majorly [3]rotaxane $\left[(3)_{2}(\gamma-C D)\right]^{6+}$, and a negligible amount of [2]rotaxane $[(3)(\gamma-C D)]^{3+}$ in the solution.

The positions of the aromatic hydrogen signals are influenced by the ring size of the cyclodextrins. Figure 3 compares the spectrum of the mixture of $\left[(3)_{2}(\gamma-C D)_{2}\right]^{6+}$ and $[2]^{+}$with the rotating-frame Overhauser effect (ROE) mode. The irradiation of the aromatic hydrogen signals of the terminal group enhanced the signals at $3.8 \mathrm{ppm}$, assigned to the hydrogens of $\gamma-\mathrm{CD}$ (at the interior side of the ring). This suggests that the 3,5-dimethoxyphenyl group of the Pt complex is at a proximity to $\gamma$-CD.

(a) $[3]^{3+}(6.0 \mathrm{mM})+[2]^{+}(12.0 \mathrm{mM})$

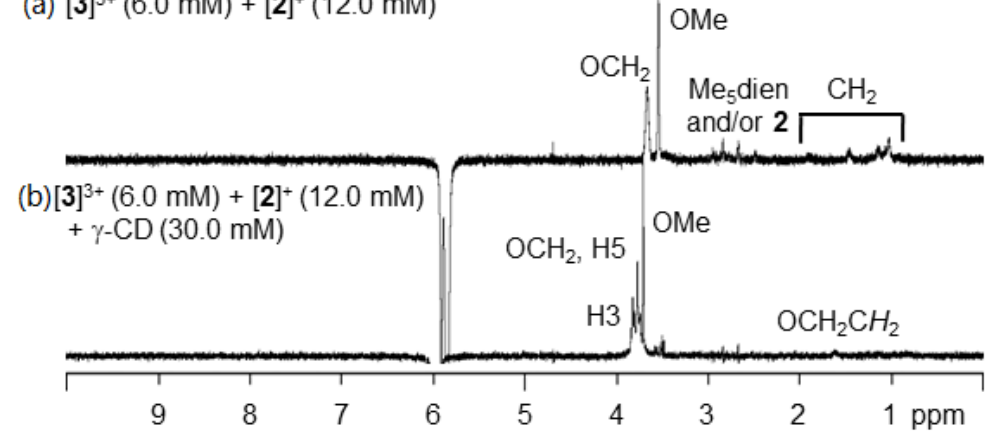

Figure 3. ${ }^{1} \mathrm{H}-\mathrm{NMR}$ spectra with the rotating-frame Overhauser effect (ROE) difference mode. (a) [3] ${ }^{3+}$ $(6.0 \mathrm{mM})+[2]^{+}(12.0 \mathrm{mM}) .(\mathbf{b})[3]^{3+}(6.0 \mathrm{mM})+[2]^{+}(12.0 \mathrm{mM})+\gamma-\mathrm{CD}(30.0 \mathrm{mM})$.

More information on the relative positions of the axle molecules and cyclodextrins was obtained by two-dimensional rotating frame Overhauser effect spectroscopy (ROESY) NMR spectroscopy experiments; the results are shown in Figures 4 and 5.

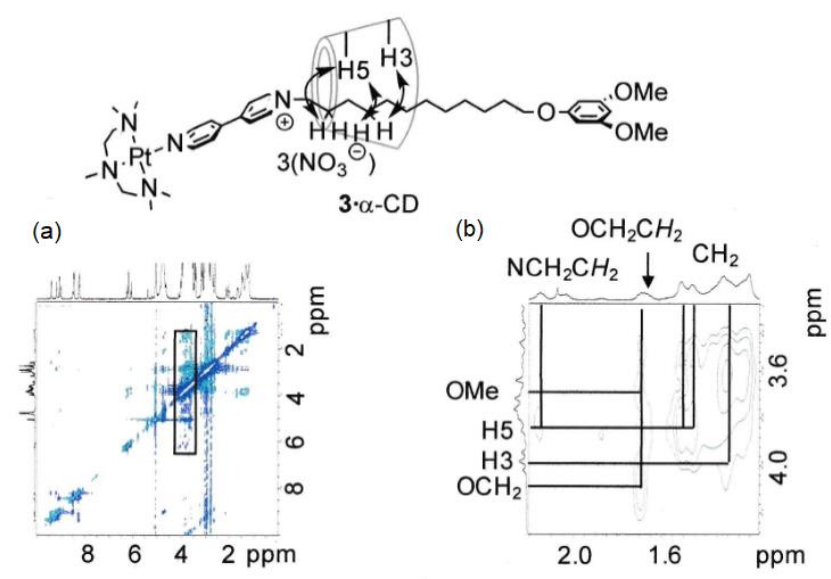

Figure 4. ROESY NMR spectra of $[(3) \cdot \alpha-C D]^{3+}\left(\mathrm{D}_{2} \mathrm{O}, 25^{\circ} \mathrm{C}, 500 \mathrm{MHz}\right)$. Total spectrum (a) and expanded spectrum (b). 


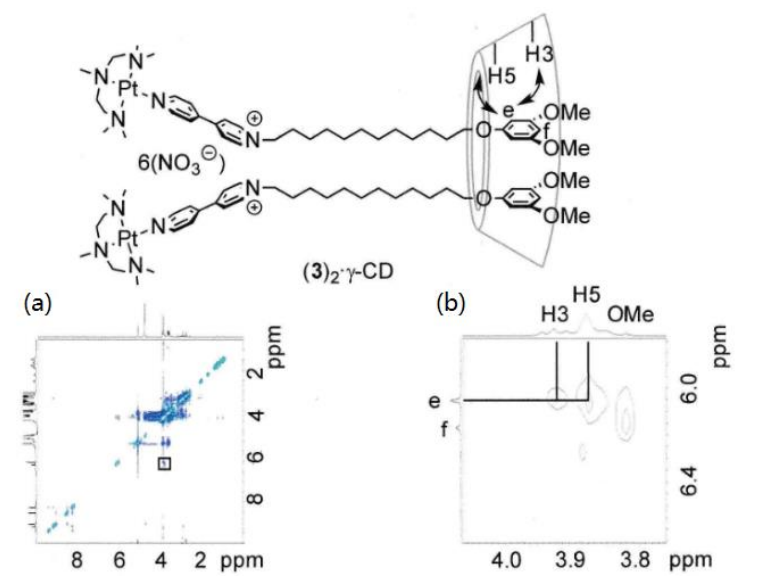

Figure 5. ROESY NMR spectra of $\left[(3)_{2} \cdot \gamma-\mathrm{CD}\right]^{6+}\left(\mathrm{D}_{2} \mathrm{O}, 25{ }^{\circ} \mathrm{C}, 500 \mathrm{MHz}\right)$. Total spectrum (a) and expanded spectrum $(\mathbf{b})$.

Figure 4(a), (b) present the cross peaks between the signals due to the $\mathrm{CH}_{2}$ group hydrogens and the signals assigned to the interior hydrogens of $\alpha-\mathrm{CD}(3.8$ and $4.0 \mathrm{ppm})$ with high intensity. The $\mathrm{NCH}_{2}$ hydrogens show significant correlation with the signals of $\alpha-\mathrm{CD}$. Considerably low-intensity cross-peaks are observed at the positions between the aromatic hydrogen signals of the terminal group of the ligand $(\mathrm{e}, \mathrm{f})$ and the interior hydrogens of $\alpha-\mathrm{CD}$. Thus, the rotaxane prefers the structure with the macrocyclic component $(\alpha-\mathrm{CD})$ at proximity to the $\mathrm{CH}_{2}$ hydrogens adjacent to the bipyridinium group. Another structure with the terminal 3,5-dimethylphenyl group and $\alpha-\mathrm{CD}$ is also observed in a much smaller amount. Figure 5 shows the spectra of a mixture containing the rotaxane composed of the Pt complex and $\gamma$-CD. Clear correlation peaks are observed, indicative of the interaction between the cyclodextrin hydrogen and 3,5-dimethoxyphenyl hydrogens (e, f) and no cross-peak between the cyclodextrin and the $\mathrm{CH}_{2}$ hydrogens. The ROESY NMR spectra of the rotaxane containing $\beta$-cyclodextrin also shows the cross-peak, indicative of the interaction between the aromatic hydrogens of the terminal group and the hydrogens of cyclodextrin.

Thus, we propose a main conformation of the rotaxanes with $\alpha-, \beta-$, and $\gamma$-cyclodextrins, as shown in Figure 6. $[(3)(\alpha-C D)]^{3+}$ contains the rotaxane having interaction between the $\mathrm{CH}_{2}$ groups adjacent to the bipyridinium group of the ligand and $\alpha$-cyclodextrin in the main, although a minor structure with the terminal 3,5-dimethoxyphenyl group and $\alpha-\mathrm{CD}$ is also formed. The rotaxanes with $\beta$-, and $\gamma$-cyclodextrins have structures with an attractive interaction between the terminal aromatic group and cyclodextrins.

Complex $[3]^{3+}$ with the cationic metal center and a long alkylene group in the ligand is expected to show an amphiphilic nature and to be aggregated in aqueous solution. The absorption spectra of the complex in aqueous solutions containing nile red showed absorption at $577 \mathrm{~nm}$. Plots of the absorbance depending on the concentration of complex 3 (Figure 7a) shows an inflection point at [3] $=1.2 \mathrm{mM}$, as shown in Figure $7 \mathrm{~b}$. It suggests formation of micelles above the concentration, and solubilization of the dye molecules in the micelles above the critical micelle concentration.

We prepared the samples for transmission electron microscopy (TEM) and atomic force microscopy (AFM) measurements by dropping the solution on carbon-coated $\mathrm{Cu}$ grids and removing the water at room temperature.

Figure 8 shows the TEM and AFM images obtained from the solutions of [3] $\left(\mathrm{NO}_{3}\right)$, $[(3)(\alpha-\mathrm{CD})]\left(\mathrm{NO}_{3}\right)_{3},[(3)(\beta-\mathrm{CD})]\left(\mathrm{NO}_{3}\right)_{3}$, and $\left[(3)_{2}(\gamma-\mathrm{CD})\right]\left(\mathrm{NO}_{3}\right)_{6}$ in aqueous media $([\mathrm{Pt}]=6.0 \mathrm{mM})$. The spots in the TEM images correspond to the $\mathrm{Pt}$ atoms in the complexes and rotaxanes. The average diameters of the spots are estimated as follows: [3] $\left(\mathrm{NO}_{3}\right)=4.0 \pm 1.1 \mathrm{~nm}$, $[(3)(\alpha-\mathrm{CD})]\left(\mathrm{NO}_{3}\right)_{3}=79.5 \pm 15.1 \mathrm{~nm}$, and $[[3](\beta-\mathrm{CD})]\left(\mathrm{NO}_{3}\right)_{3}=6.0 \pm 1.3 \mathrm{~nm}$. The rotaxane $\left[(3)_{2}(\gamma-\mathrm{CD})\right]\left(\mathrm{NO}_{3}\right)_{6}$ provided elongated spots with a size of $125,800 \times 108 \mathrm{~nm}$, which were assigned to the rod micelles formed in the solution. The spots observed in the TEM image of $[(3)(\alpha-\mathrm{CD})]\left(\mathrm{NO}_{3}\right)_{3}$ are 
much larger than the aggregates of $[3]\left(\mathrm{NO}_{3}\right)$ and $[(3)(\beta-\mathrm{CD})]\left(\mathrm{NO}_{3}\right)_{3}$. Many of the spots show contrast between a dark particle edge and less-dark central region. This suggests the formation of vesicles by aggregated rotaxanes. Since the solutions contain both rotaxanes and complex $[2]^{+}$added to enhance the formation of the rotaxane, the aggregates, observed in the TEM images, also contain the rotaxane and the cationic complex without bipyridinium ligands. The size and shape of the aggregates observed by the micrograph differ depending on the size of CDs, in spite of the co-existence of complex [2] $]^{+}$. The formed aggregates have a regulated size and different sizes and shapes depending on the CD involved in the rotaxane molecules, despite the presence of such impurities.
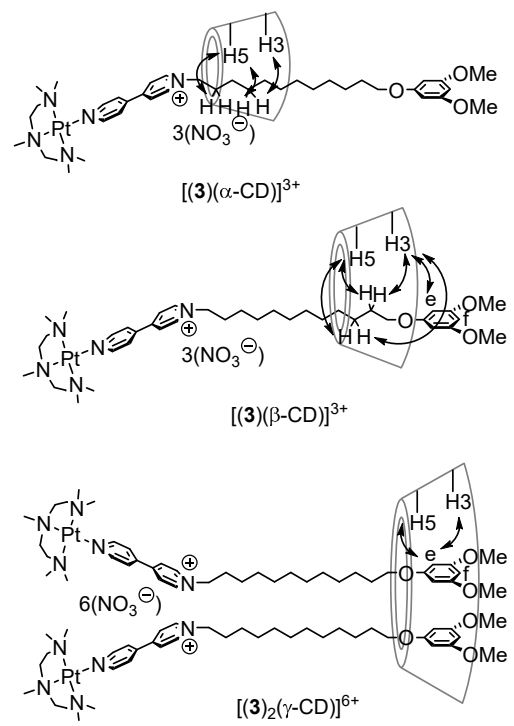

Figure 6. Conformation of polyrotaxanes based on ROESY NMR spectra measurement. Symbols e and $\mathrm{f}$ are due to the aromatic hydrogens at the positions. They correspond to the structures in Scheme 2.

(a)

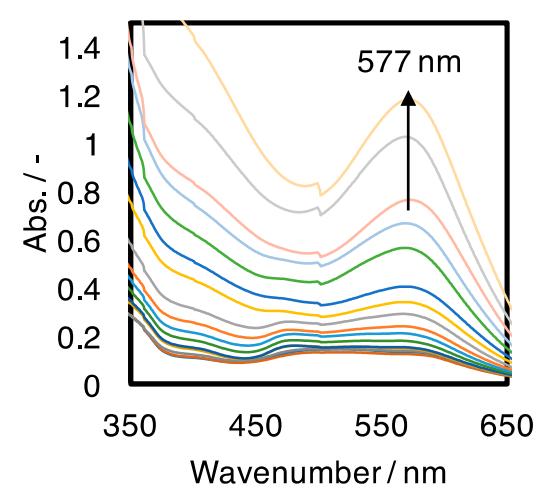

(b)

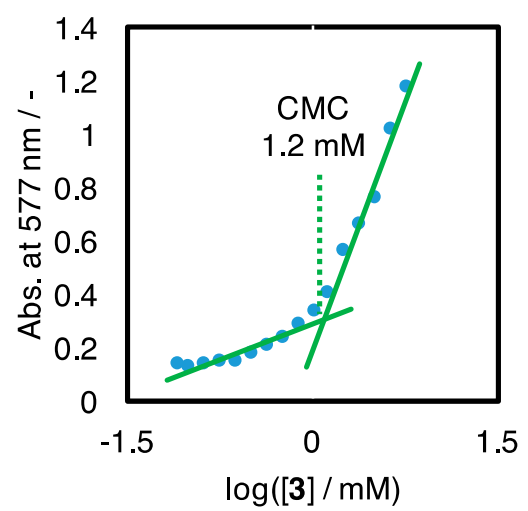

Figure 7. (a) Absorption spectra of nile red depending on coexisting complex 3 in aqueous solutions $([3]=0.08-5.68 \mathrm{mM}$, [nile red] $=10 \mu \mathrm{M})$. (b) Plots of absorbance at $577 \mathrm{~nm}$ vs. the concentration of 3 . 
(a)
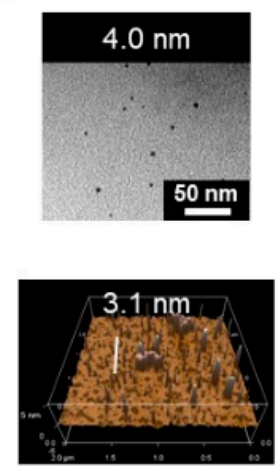

(b)
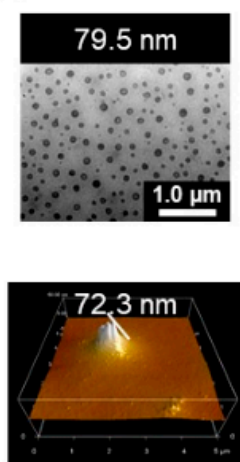

(c)
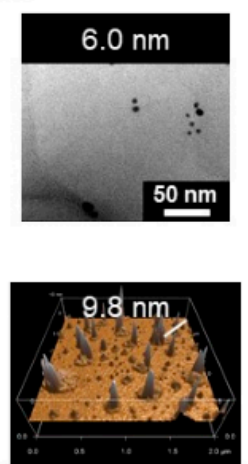

(d)
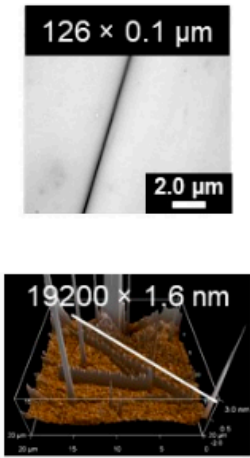

Figure 8. Transmission electron microscopy (TEM) images (upper) and AFM image (lower) for each sample. Measurement was conducted after dropping the solution on the surface of the carbon-coated Cu grids. (a) $[3]^{3+}=6.0 \mathrm{mM},[2]^{+}=12.0 \mathrm{mM}$. (b) $[(3) \cdot \alpha-C D]^{3+}=3.4 \mathrm{mM},[3]^{3+}=2.6 \mathrm{mM},[2]^{+}=12.0 \mathrm{mM}$, $[\alpha-C D]=8.6 \mathrm{mM}$. (c) $[(3) \cdot \beta-\mathrm{CD}]^{3+}=6.0 \mathrm{mM},[2]^{+}=12.0 \mathrm{mM}$. (d) $\left[(3)_{2} \cdot \gamma-\mathrm{CD}\right]^{6+}=3.0 \mathrm{mM},[2]=12.0 \mathrm{mM}$.

\subsection{Preparation of Pt Nanoparticles}

The addition of $\mathrm{NaBH}_{4}$ to a solution of the $\mathrm{Pt}$ complex with and without CDs afforded $\mathrm{Pt}$ nanoparticles via reduction of the $\mathrm{Pt}(\mathrm{II})$ compound. The original aqueous solution was yellow; upon the addition of $\mathrm{NaBH}_{4}$ (30 equiv./Pt) dispersed in $\mathrm{H}_{2} \mathrm{O}(1.0 \mathrm{~mL})$, the color changed to blue at first, and subsequently to brown. The precipitation of a solid material was not observed. The resulting aqueous solution was dropped onto the $\mathrm{Cu}$ grid and was analyzed by TEM after removing the water.

Figure 9 presents the TEM images of the Pt particles obtained by the reduction of [3] ${ }^{3+}$ and its rotaxanes with $\alpha, \beta, \gamma$-CDs at $3.0 \mathrm{mM} \mathrm{Pt}$. In all cases, the measurements revealed the presence of sphere-shaped spots with similar sizes. The aggregation of the $\mathrm{Pt}$ complex and its rotaxanes, as micelles, vesicles, and rod-micelles, is not directly related to the shape of the Pt nanoparticles obtained by the reduction. The average radii of the nanoparticles obtained from $[3]^{3+}$ increase slightly with an increase in the concentration, $1.4 \pm 0.4 \mathrm{~nm}(0.05 \mathrm{mM}), 1.8 \pm 0.5 \mathrm{~nm}(0.75 \mathrm{mM}), 1.9 \pm 0.4 \mathrm{~nm}$ (1.5 mM), $2.0 \pm 0.4 \mathrm{~nm}(3.0 \mathrm{mM}), 3.1 \pm 0.8 \mathrm{~nm}(6.0 \mathrm{mM})$. The average size of the formed Pt particles are as follows: $1.3 \pm 0.4 \mathrm{~nm}(0.05 \mathrm{mM}), 1.8 \pm 0.5 \mathrm{~nm}(0.75 \mathrm{mM}), 1.9 \pm 0.4 \mathrm{~nm}(1.5 \mathrm{mM}), 2.0 \pm 0.4 \mathrm{~nm}$ (3.0 mM), $2.3 \pm 0.8 \mathrm{~nm}(6.0 \mathrm{mM})$ for $[(3)(\alpha-\mathrm{CD})]\left(\mathrm{NO}_{3}\right)_{3}, 1.7 \pm 0.4 \mathrm{~nm}(0.05 \mathrm{mM}), 2.0 \pm 0.5 \mathrm{~nm}(0.75 \mathrm{mM})$, $2.1 \pm 0.3 \mathrm{~nm}(1.5 \mathrm{mM}), 2.6 \pm 0.4 \mathrm{~nm}(3.0 \mathrm{mM})$, and $2.9 \pm 0.5 \mathrm{~nm}(6.0 \mathrm{mM})$ for $[[3](\beta-C D)]\left(\mathrm{NO}_{3}\right)_{3}$, and $1.9 \pm 0.4 \mathrm{~nm}(0.05 \mathrm{mM}), 2.2 \pm 0.5 \mathrm{~nm}(0.75 \mathrm{mM}), 2.5 \pm 0.3 \mathrm{~nm}(1.5 \mathrm{mM}), 2.7 \pm 0.5 \mathrm{~nm}(3.0 \mathrm{mM})$, and $2.8 \pm 0.5 \mathrm{~nm}(6.0 \mathrm{mM})$ for $\left[(3)_{2}(\gamma-\mathrm{CD})\right]\left(\mathrm{NO}_{3}\right)_{3}$. The treatment of a mixture of ligand $\left([1]^{+}, 6.0 \mathrm{mM}\right)$, Pt complex $\left([2]^{+}, 18 \mathrm{mM}\right)$, and $\alpha-\mathrm{CD}(12 \mathrm{mM})$ in an aqueous solution with $\mathrm{NaBH}_{4}$ did not form the nanoparticles, but caused the deposition of a black solid composed of metallic $\mathrm{Pt}$.

The reduction of $[(3)(\beta-C D)]\left(\mathrm{NO}_{3}\right)_{3}$ by $\mathrm{NaBH}_{4}$ in the presence of tetrakis(4-carboxyphenyl)porphyrin (TCPP) formed Pt particles with a much larger particle size than those without addition of TCPP, as shown in the TEM images (Figure 10a-c). TCPP and the Pt complex compete for coordination with $\beta-C D$ because both can form rotaxane or pseudorotaxane with $\beta-C D$. The high stability of the Pt nanoparticles from the rotaxanes in this study is partly attributed to the protection of the cyclodextrins on the surface of the $\mathrm{Pt}$ particles. Stable metal nanoparticles protected by functionalized cyclodextrins were synthesized and used as efficient catalysts for synthetic organic reactions [48-50].

Thermal stability of Pt nanoparticles obtained by the above procedures was compared. The particles obtained from the reduction of complex $[3]^{+}$are stable at room temperature; however, their particle size increases on heating the solution at $70{ }^{\circ} \mathrm{C}$ for $3 \mathrm{~h}$ (from $2.0 \pm 0.4 \mathrm{~nm}$ to $3.2 \pm 0.6 \mathrm{~nm}$ ). The size of the Pt particles obtained from the rotaxanes, however, did not change even after heat treatments: $1.9 \pm 0.4 \mathrm{~nm}$ to $2.0 \pm 0.4 \mathrm{~nm}$ for $[(3)(\alpha-\mathrm{CD})]\left(\mathrm{NO}_{3}\right)_{3}, 2.6 \pm 0.4 \mathrm{~nm}$ to $2.5 \pm 0.5 \mathrm{~nm}$ for $[(3)(\beta-\mathrm{CD})]\left(\mathrm{NO}_{3}\right)_{3}$, and $2.8 \pm 0.6 \mathrm{~nm}$ to $2.8 \pm 0.6 \mathrm{~nm}$ for $\left[(3)_{2}(\gamma-\mathrm{CD})\right]\left(\mathrm{NO}_{3}\right)_{3}$. 
(a)

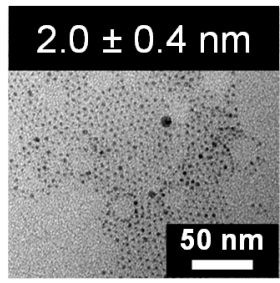

(c)

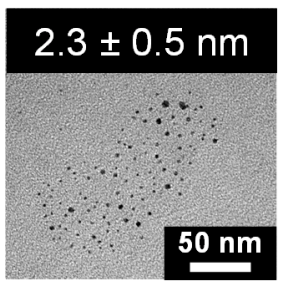

(b)

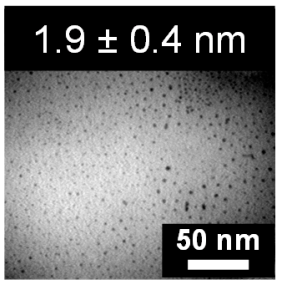

(d)

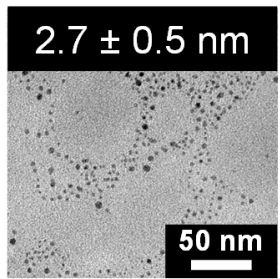

Figure 9. TEM images of the Pt nanoparticles obtained from the reduction of the complex or rotaxane in an aqueous solution $(3.0 \mathrm{mM})$. Measurement was conducted after dropping the solution on the surface of carbon-coated $\mathrm{Cu}$ grids. (a) $[3]\left(\mathrm{NO}_{3}\right),(\mathbf{b})[[3](\alpha-\mathrm{CD})]\left(\mathrm{NO}_{3}\right)_{3}$, (c) $[[3](\beta-\mathrm{CD})]\left(\mathrm{NO}_{3}\right)_{3}$, (d) $\left[[3]_{2}(\gamma-\mathrm{CD})\right]\left(\mathrm{NO}_{3}\right)_{6}$.

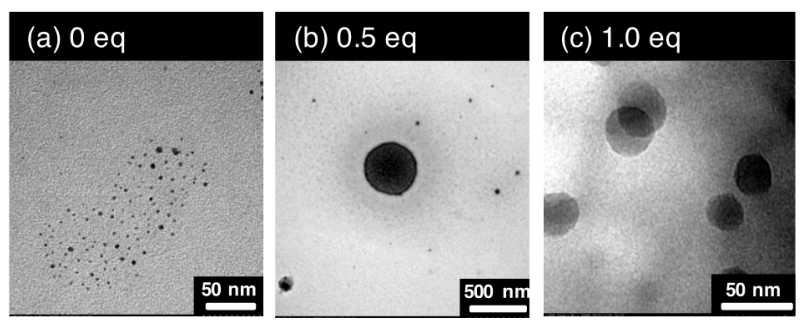

Figure 10. TEM images of the Pt nanoparticles obtained by $\mathrm{NaBH}_{4}$ reduction of $[(3)(\beta-\mathrm{CD})]\left(\mathrm{NO}_{3}\right)_{3}$ in an aqueous solution $(3.0 \mathrm{mM})$ : (a) as prepared, (b) after addition of tetrakis(4-carboxyphenyl)porphyrin (TCPP) (0.5 eq to Pt), (c) after further addition of TCPP (1.0 eq to Pt).

\section{Materials and Methods}

\subsection{General}

All the chemicals were commercially available from Tokyo Kasei Chemicals Co. ${ }^{1} \mathrm{H}-$ and ${ }^{13} \mathrm{C}\left\{{ }^{1} \mathrm{H}\right\}-\mathrm{NMR}$ spectra were acquired on a Bruker AV-400M $(400 \mathrm{MHz})$ and a JEOL JNM-500 (500 MHz). The chemical shifts were referenced with respect to $\mathrm{CHCl}_{3}(\delta 7.26), \mathrm{HDO}(\delta$ 4.79) for ${ }^{1} \mathrm{H}$, and $\mathrm{CDCl}_{3}(\delta 77.0)$, DSS (sodium 3-(trimethylsilyl)-1-propanesulfonate) $(\delta 0.0)$ for ${ }^{13} \mathrm{C}$ as internal standards. High resolution electrospray ionization mass spectrometry (HR-ESI-MS) was recorded on a Bruker micrOTOF II. The TEM was performed at $100 \mathrm{kV}$ using Hitachi H-7650 Zero with collodion/carbon-support film grids, COL-C15 STEM Cu150P (Okenshoji, Japan). The AFM was performed using Oxford Instruments Cypher S using OLYMPUS AC160TS.

\subsection{Preparation of $\left[4,4^{\prime}-\right.$ bpy-N- $\left.-\left(\mathrm{CH}_{2}\right)_{12} \mathrm{OC}_{6} \mathrm{H}_{3}-3,5-(\mathrm{OMe})_{2}\right][\mathrm{Br}]\left([1]^{+} \mathrm{Br}{ }^{-}\right)$and} $\left[4,4^{\prime}-b p y-\mathrm{N}-\left(\mathrm{CH}_{2}\right)_{12} \mathrm{OC}_{6} \mathrm{H}_{3}-3,5-(\mathrm{OMe})_{2}\right]\left[\mathrm{NO}_{3}\right]\left([1]^{+}\left(\mathrm{NO}_{3}\right)^{-}\right)$

The title compound with $\mathrm{Br}^{-}$was prepared according to the literature. ${ }^{1} \mathrm{H}-\mathrm{NMR}(400 \mathrm{MHz}$, $\mathrm{D}_{2} \mathrm{O}$, r.t.): $\delta 0.88-1.26\left(\mathrm{~m}, 16 \mathrm{H}, \mathrm{CH}_{2}\right), 1.39$ (quin, $2 \mathrm{H}, \mathrm{OCH}_{2} \mathrm{CH}_{2}, J=6.6 \mathrm{~Hz}$ ), 1.95 (quin, $2 \mathrm{H}, \mathrm{NCH}_{2} \mathrm{CH}_{2}$, $J=6.6 \mathrm{~Hz}), 3.54\left(\mathrm{t}, 2 \mathrm{H}, \mathrm{OCH}_{2}, J=7.0 \mathrm{~Hz}\right), 3.56\left(\mathrm{~s}, 6 \mathrm{H}, \mathrm{OCH}_{3}\right), 4.67\left(\mathrm{t}, 2 \mathrm{H}, \mathrm{NCH}_{2}, J=6.8 \mathrm{~Hz}\right)$, $5.73\left(\mathrm{~s}, 2 \mathrm{H}, \mathrm{C}_{6} \mathrm{H}_{3}\right), 5.90\left(\mathrm{~s}, 1 \mathrm{H}, \mathrm{C}_{6} \mathrm{H}_{3}\right), 7.83\left(\mathrm{~d}, 2 \mathrm{H}, \mathrm{C}_{10} \mathrm{H}_{8} \mathrm{~N}_{2}, J=6.3 \mathrm{~Hz}\right), 8.36\left(\mathrm{~d}, 2 \mathrm{H}, \mathrm{C}_{10} \mathrm{H}_{8} \mathrm{~N}_{2}, J=\right.$ $6.6 \mathrm{~Hz}), 8.75\left(\mathrm{~d}, 2 \mathrm{H}, \mathrm{C}_{10} \mathrm{H}_{8} \mathrm{~N}_{2}, J=6.2 \mathrm{~Hz}\right), 8.94\left(\mathrm{~d}, 2 \mathrm{H}, \mathrm{C}_{10} \mathrm{H}_{8} \mathrm{~N}_{2}, J=6.8 \mathrm{~Hz}\right) .{ }^{13} \mathrm{C}\left\{{ }^{1} \mathrm{H}\right\}-\mathrm{NMR}(125 \mathrm{MHz}$, $\mathrm{CDCl}_{3}$, r.t.): $\delta 26.1\left(\mathrm{CH}_{2}\right), 26.3\left(\mathrm{CH}_{2}\right), 29.2\left(\mathrm{CH}_{2}\right), 29.3\left(\mathrm{CH}_{2}\right), 29.4\left(\mathrm{CH}_{2}\right), 29.5\left(\mathrm{CH}_{2}\right), 29.6\left(\mathrm{CH}_{2}\right), 29.7$ 
$\left(\mathrm{CH}_{2}\right), 29.9\left(\mathrm{CH}_{2}\right), 30.0\left(\mathrm{CH}_{2}\right), 55.5\left(\mathrm{OCH}_{2}\right), 62.1\left(\mathrm{NCH}_{2}\right), 68.2\left(\mathrm{OCH}_{3}\right), 92.9\left(\mathrm{C}_{6} \mathrm{H}_{3}\right), 93.5\left(\mathrm{C}_{6} \mathrm{H}_{3}\right), 121.6$ $\left(\mathrm{C}_{10} \mathrm{H}_{8} \mathrm{~N}_{2}\right), 125.9\left(\mathrm{C}_{10} \mathrm{H}_{8} \mathrm{~N}_{2}\right), 141.1\left(\mathrm{C}_{10} \mathrm{H}_{8} \mathrm{~N}_{2}\right), 145.8\left(\mathrm{C}_{10} \mathrm{H}_{8} \mathrm{~N}_{2}\right), 151.7\left(\mathrm{C}_{10} \mathrm{H}_{8} \mathrm{~N}_{2}\right), 154.0\left(\mathrm{C}_{10} \mathrm{H}_{8} \mathrm{~N}_{2}\right)$, $161.2\left(\mathrm{C}_{6} \mathrm{H}_{3}\right), 161.6\left(\mathrm{C}_{6} \mathrm{H}_{3}\right)$.

Compound with $\mathrm{NO}_{3}$ anion. ${ }^{1} \mathrm{H}-\mathrm{NMR}\left(500 \mathrm{MHz}, \mathrm{D}_{2} \mathrm{O}\right.$, r.t.): $\delta 0.84-1.23\left(\mathrm{~m}, 16 \mathrm{H}, \mathrm{CH}_{2}\right), 1.34$ (quin, $2 \mathrm{H}, \mathrm{OCH}_{2} \mathrm{CH}_{2}, J=6.4 \mathrm{~Hz}$ ), 1.95 (quin, $2 \mathrm{H}, \mathrm{NCH}_{2} \mathrm{CH}_{2}, J=6.9 \mathrm{~Hz}$ ), $3.49\left(\mathrm{~s}, 6 \mathrm{H}, \mathrm{OCH}_{3}\right), 3.49$ (brs, $2 \mathrm{H}$, $\left.\mathrm{OCH}_{2}\right), 4.70\left(\mathrm{t}, 2 \mathrm{H}, \mathrm{NCH}_{2}, J=7.2 \mathrm{~Hz}\right), 5.68\left(\mathrm{~s}, 2 \mathrm{H}, \mathrm{C}_{6} \mathrm{H}_{3}\right), 5.81\left(\mathrm{~s}, 1 \mathrm{H}, \mathrm{C}_{6} \mathrm{H}_{3}\right), 7.84\left(\mathrm{~d}, 2 \mathrm{H}, \mathrm{C}_{10} \mathrm{H}_{8} \mathrm{~N}_{2}, J=\right.$ $5.5 \mathrm{~Hz}), 8.38\left(\mathrm{~d}, 2 \mathrm{H}, \mathrm{C}_{10} \mathrm{H}_{8} \mathrm{~N}_{2}, J=6.5 \mathrm{~Hz}\right), 8.72\left(\mathrm{~d}, 2 \mathrm{H}, \mathrm{C}_{10} \mathrm{H}_{8} \mathrm{~N}_{2}, J=5.0 \mathrm{~Hz}\right), 9.00\left(\mathrm{~d}, 2 \mathrm{H}, \mathrm{C}_{10} \mathrm{H}_{8} \mathrm{~N}_{2}\right.$ ， $J=6.5 \mathrm{~Hz}) .{ }^{1} \mathrm{H}-\mathrm{NMR}\left(400 \mathrm{MHz}, \mathrm{CDCl}_{3}\right.$, r.t.): $\delta 1.17-1.48\left(\mathrm{~m}, 16 \mathrm{H}, \mathrm{CH}_{2}\right), 1.72$ (brs, $\left.2 \mathrm{H}, \mathrm{OCH}_{2} \mathrm{CH}_{2}\right)$, 2.01 (brs, $\left.2 \mathrm{H}, \mathrm{NCH}_{2} \mathrm{CH}_{2}\right), 3.74\left(\mathrm{~s}, 6 \mathrm{H}, \mathrm{OCH}_{3}\right), 3.88\left(\mathrm{t}, 2 \mathrm{H}, \mathrm{OCH}_{2}, J=7.9 \mathrm{~Hz}\right), 4.76\left(\mathrm{t}, 2 \mathrm{H}, \mathrm{NCH}_{2}, J=\right.$ $6.2 \mathrm{~Hz}), 6.05\left(\mathrm{~s}, 2 \mathrm{H}, \mathrm{C}_{6} \mathrm{H}_{3}\right), 6.06\left(\mathrm{~s}, 1 \mathrm{H}, \mathrm{C}_{6} \mathrm{H}_{3}\right), 7.67\left(\mathrm{~d}, 2 \mathrm{H}, \mathrm{C}_{10} \mathrm{H}_{8} \mathrm{~N}_{2}, J=4.6 \mathrm{~Hz}\right), 8.28\left(\mathrm{~d}, 2 \mathrm{H}, \mathrm{C}_{10} \mathrm{H}_{8} \mathrm{~N}_{2}\right.$, $J=5.5 \mathrm{~Hz}), 8.85\left(\mathrm{brs}, 2 \mathrm{H}, \mathrm{C}_{10} \mathrm{H}_{8} \mathrm{~N}_{2}, J=5.0 \mathrm{~Hz}\right), 9.19\left(\mathrm{~d}, 2 \mathrm{H}, \mathrm{C}_{10} \mathrm{H}_{8} \mathrm{~N}_{2}, J=5.8 \mathrm{~Hz}\right)$.

\subsection{Preparation of $\left[\mathrm{Pt}\left(\mathrm{Me}_{5}\right.\right.$ dien $\left.) \mathrm{Cl}\right] \mathrm{Cl}([2] \mathrm{Cl})$}

The complex was prepared by slight modification of the literature method. $\mathrm{MeOH}(30 \mathrm{~mL})$ was added to $\mathrm{Me}_{5}$ dien $(2.0 \mathrm{~mL}, 9.5 \mathrm{mmol})$ to form a solution. Further addition of $c i s-\mathrm{PtCl}_{2}(\mathrm{dmso})_{2}(4.0 \mathrm{~g}$, $9.5 \mathrm{mmol})$, and addition of $\mathrm{MeOH}(20 \mathrm{~mL})$ was followed by heating the mixture for $6 \mathrm{~h}$ under reflux. Cooling the solution at room temperature and evaporation of the solvent left a pale brown solid. Recrystallization of the solid product by acetone $/ \mathrm{CH}_{2} \mathrm{Cl}_{2}$ yielded off-white crystals of [ $\left.\mathrm{Pt}\left(\mathrm{Me}_{5} \mathrm{dien}\right) \mathrm{Cl}\right] \mathrm{Cl}$ ([2]Cl) $(4.1 \mathrm{~g}, 9.3 \mathrm{mmol}, 98 \%) .{ }^{1} \mathrm{H}-\mathrm{NMR}\left(500 \mathrm{MHz}, \mathrm{D}_{2} \mathrm{O}\right.$, r.t.): $\delta 2.79\left(\mathrm{~s}, 6 \mathrm{H}, \mathrm{CH}_{3}, J_{\mathrm{Pt}-\mathrm{H}}=10.1 \mathrm{~Hz}\right), 2.93$ $\left(\mathrm{t}, 2 \mathrm{H}, \mathrm{CH}_{2}, J=3.2 \mathrm{~Hz}\right), 2.96\left(\mathrm{t}, 2 \mathrm{H}, \mathrm{CH}_{2}, J=3.7 \mathrm{~Hz}\right), 2.98\left(\mathrm{~s}, 6 \mathrm{H}, \mathrm{CH}_{3}, J_{\mathrm{Pt}-\mathrm{H}}=12.5 \mathrm{~Hz}\right), 3.11\left(\mathrm{~s}, 3 \mathrm{H}, \mathrm{CH}_{3}\right.$, $\left.\left.J_{\mathrm{Pt}-\mathrm{H}}=21.0 \mathrm{~Hz}\right), 3.50\left(\mathrm{td}, 2 \mathrm{H}, \mathrm{CH}_{2}, J=14.1,3.5 \mathrm{~Hz}\right), 3.72\left(\mathrm{td}, 2 \mathrm{H}, \mathrm{CH}_{2}, J=13.3,3.9 \mathrm{~Hz}\right) .{ }^{13} \mathrm{C}^{1}{ }^{1} \mathrm{H}\right\}-\mathrm{NMR}$ $\left(125 \mathrm{MHz}, \mathrm{D}_{2} \mathrm{O}\right.$, r.t.): $\delta 48.4\left(\mathrm{CH}_{3}\right), 54.4\left(\mathrm{CH}_{3}\right), 55.7\left(\mathrm{CH}_{3}\right), 64.9\left(\mathrm{CH}_{2}\right), 70.7\left(\mathrm{CH}_{2}\right)$.

Treatment of the product by $\mathrm{AgNO}_{3}$ yielded $\left[\mathrm{Pt}\left(\mathrm{Me}_{5}\right.\right.$ dien $\left.) \mathrm{NO}_{3}\right] \mathrm{NO}_{3}\left([2]\left(\mathrm{NO}_{3}\right)\right)$ in high yield (168.0 mg, $0.33 \mathrm{mmol}, 85 \%) .{ }^{1} \mathrm{H}-\mathrm{NMR}\left(400 \mathrm{MHz}, \mathrm{D}_{2} \mathrm{O}\right.$, r.t.): $\delta 2.79\left(\mathrm{~s}, 6 \mathrm{H}, \mathrm{CH}_{3}, J_{\mathrm{Pt}-\mathrm{H}}=10.3 \mathrm{~Hz}\right), 2.94$ $\left(\mathrm{t}, 2 \mathrm{H}, \mathrm{CH}_{2}, J=3.8 \mathrm{~Hz}\right), 2.96\left(\mathrm{~s}, 6 \mathrm{H}, \mathrm{CH}_{3}\right), 2.97\left(\mathrm{t}, 2 \mathrm{H}, \mathrm{CH}_{2}, J=3.5 \mathrm{~Hz}\right), 3.09\left(\mathrm{~s}, 3 \mathrm{H}, \mathrm{CH}_{3}, J_{\mathrm{Pt}-\mathrm{H}}=22.5 \mathrm{~Hz}\right)$, $\left.3.52\left(\mathrm{td}, 2 \mathrm{H}, \mathrm{CH}_{2}, J=14.0,3.8 \mathrm{~Hz}\right), 3.70\left(\mathrm{td}, 2 \mathrm{H}, \mathrm{CH}_{2}, J=13.3,4.2 \mathrm{~Hz}\right) .{ }^{13} \mathrm{C}^{1} \mathrm{H}\right\}-\mathrm{NMR}\left(125 \mathrm{MHz}, \mathrm{D}_{2} \mathrm{O}\right.$, r.t.): $\delta 48.4\left(\mathrm{CH}_{3}\right), 54.4\left(\mathrm{CH}_{3}\right), 55.7\left(\mathrm{CH}_{3}\right), 64.9\left(\mathrm{CH}_{2}\right), 70.7\left(\mathrm{CH}_{2}\right)$.

\subsection{Preparation of $\left[\mathrm{Pt}\left(\mathrm{Me}{ }_{5}\right.\right.$ dien $\left.)\left(4,4^{\prime}-b p y-\mathrm{N}-\left(\mathrm{CH}_{2}\right)_{12} \mathrm{OC}_{6} \mathrm{H}_{3}-3,5-(\mathrm{OMe})_{2}\right)\right]\left[\mathrm{NO}_{3}\right]_{3}\left([3]\left(\mathrm{NO}_{3}\right)\right)$}

A suspension of [1] $\left(\mathrm{NO}_{3}\right)(372 \mathrm{mg}, 0.67 \mathrm{mmol})$ in water $(100 \mathrm{~mL})$ was stirred, and [2]Cl $(879 \mathrm{mg}$, $2.0 \mathrm{mmol})$ and $\mathrm{AgNO}_{3}(792 \mathrm{mg}, 4.67 \mathrm{mmol})$ were added to the mixture, and mixed with water $(50 \mathrm{~mL})$. Water $(50 \mathrm{~mL})$ was added to the mixture, and the resulting suspension was heated for $66 \mathrm{~h}$ at $80^{\circ} \mathrm{C}$. After cooling to room temperature, the reaction mixture was filtered to remove $\mathrm{AgCl}$. Evaporation of the solvent from the filtrate produced a brown solid $(1.40 \mathrm{~g}) \cdot{ }^{1} \mathrm{H}$ - and ${ }^{13} \mathrm{C}\left\{{ }^{1} \mathrm{H}\right\}-\mathrm{NMR}$ spectra of the solid showed that it contained [ $\mathrm{Pt}\left(\mathrm{Me}_{5}\right.$ dien $\left.)\left(4,4^{\prime}-\mathrm{bpy}-\mathrm{N}-\left(\mathrm{CH}_{2}\right)_{12} \mathrm{OC}_{6} \mathrm{H}_{3}-3,5-(\mathrm{OMe})_{2}\right)\right]\left[\mathrm{NO}_{3}\right]_{3}(3)$ and 2 in 1:2 molar ratio. ${ }^{1} \mathrm{H}-\mathrm{NMR}\left(500 \mathrm{MHz}, \mathrm{D}_{2} \mathrm{O}\right.$, r.t.): $\delta 1.00-1.40\left(\mathrm{~m}, 16 \mathrm{H}, \mathrm{CH}_{2}\right), 1.57$ (quin, $2 \mathrm{H}, \mathrm{OCH}_{2} \mathrm{CH}_{2}, J=$ $6.7 \mathrm{~Hz}$ ), 2.01 (quin, $\left.2 \mathrm{H}, \mathrm{NCH}_{2} \mathrm{CH}_{2}, J=6.5 \mathrm{~Hz}\right), 2.50-3.20\left(19 \mathrm{H}, \mathrm{NCH}_{3}, \mathrm{NCH}_{2}\right), 3.43-3.80\left(4 \mathrm{H}, \mathrm{NCH}_{2}\right)$, $3.54\left(\mathrm{~s}, 6 \mathrm{H}, \mathrm{OCH}_{3}\right), 3.73\left(\mathrm{brs}, 2 \mathrm{H}, \mathrm{OCH}_{2}\right), 4.64\left(\mathrm{t}, 2 \mathrm{H}, \mathrm{NCH}_{2}, J=7.2 \mathrm{~Hz}\right), 5.96\left(\mathrm{~s}, 2 \mathrm{H}, \mathrm{C}_{6} \mathrm{H}_{3}\right), 6.02(\mathrm{~s}, 1 \mathrm{H}$, $\left.\mathrm{C}_{6} \mathrm{H}_{3}\right), 8.22\left(\mathrm{~d}, 2 \mathrm{H}, \mathrm{C}_{10} \mathrm{H}_{8} \mathrm{~N}_{2}, 4.5\right), 8.47\left(\mathrm{~d}, 2 \mathrm{H}, \mathrm{C}_{10} \mathrm{H}_{8} \mathrm{~N}_{2}, J=7.0 \mathrm{~Hz}\right), 9.01\left(\mathrm{~d}, 2 \mathrm{H}, \mathrm{C}_{10} \mathrm{H}_{8} \mathrm{~N}_{2}, J=6.5 \mathrm{~Hz}\right)$, $\left.9.17\left(\mathrm{~d}, 1 \mathrm{H}, \mathrm{C}_{10} \mathrm{H}_{8} \mathrm{~N}_{2}, J=5.5 \mathrm{~Hz}\right), 9.41\left(\mathrm{~d}, 1 \mathrm{H}, \mathrm{C}_{10} \mathrm{H}_{8} \mathrm{~N}_{2}, J=6.0 \mathrm{~Hz}\right) .{ }^{13} \mathrm{C}^{1} \mathrm{H}\right\}-\mathrm{NMR}\left(100 \mathrm{MHz}, \mathrm{D}_{2} \mathrm{O}\right.$, r.t.): $\delta 30.5\left(\mathrm{CH}_{2}\right), 31.3\left(\mathrm{CH}_{2}\right), 31.3\left(\mathrm{CH}_{2}\right), 31.6\left(\mathrm{OCH}_{2} \mathrm{CH}_{2}\right), 31.7\left(\mathrm{CH}_{2}\right), 31.8\left(\mathrm{CH}_{2}\right), 31.8\left(2 \mathrm{CH}_{2}\right) 33.2$ $\left(\mathrm{NCH}_{2} \mathrm{CH}_{2}\right), 47.6\left(\mathrm{NCH}_{2}\right), 53.4\left(\mathrm{NCH}_{3}\right), 55.2\left(\mathrm{NCH}_{3}\right), 63.9\left(\mathrm{NCH}_{2}\right), 64.0\left(\mathrm{NCH}_{2}\right), 69.9\left(\mathrm{NCH}_{2}\right), 70.3$ $\left(\mathrm{OCH}_{2}\right)$, $94.7\left(\mathrm{C}_{6} \mathrm{H}_{3}\right), 95.6\left(\mathrm{C}_{6} \mathrm{H}_{3}\right), 128.4\left(\mathrm{C}_{10} \mathrm{H}_{8} \mathrm{~N}_{2}\right), 128.6\left(\mathrm{C}_{10} \mathrm{H}_{8} \mathrm{~N}_{2}\right), 147.3\left(\mathrm{C}_{10} \mathrm{H}_{8} \mathrm{~N}_{2}\right), 147.9\left(\mathrm{C}_{10} \mathrm{H}_{8} \mathrm{~N}_{2}\right)$, $153.2\left(\mathrm{C}_{10} \mathrm{H}_{8} \mathrm{~N}_{2}\right), 155.6\left(\mathrm{C}_{10} \mathrm{H}_{8} \mathrm{~N}_{2}\right), 156.1\left(\mathrm{C}_{10} \mathrm{H}_{8} \mathrm{~N}_{2}\right), 163.0\left(\mathrm{C}_{6} \mathrm{H}_{3}\right), 163.5\left(\mathrm{C}_{6} \mathrm{H}_{3}\right)$. ESI-MS (eluent: $\left.\mathrm{H}_{2} \mathrm{O}\right)$ : calcd for $\left[\mathrm{C}_{39} \mathrm{H}_{64} \mathrm{~N}_{5} \mathrm{O}_{3} \mathrm{Pt}\right]^{2+} 422.73$, found $422.73\left(\mathrm{M}^{2+}\right)$.

\subsection{Rotaxane of $\alpha-\mathrm{CD}$ with $\left[\mathrm{Pt}\left(\mathrm{Me} \mathrm{e}_{5}\right.\right.$ dien $\left.\left.)\left(4,4^{\prime}-\mathrm{bpy}-\mathrm{N}-\left(\mathrm{CH}_{2}\right)_{12} \mathrm{OC}_{6} \mathrm{H}_{3}-3,5-(\mathrm{OMe})_{2}\right)\right]\left[\mathrm{NO}_{3}\right]_{3}\right)$}

A mixture of [3] $]^{+}$and [2] ${ }^{+}$in 1:2 molar ratio $(266.2 \mathrm{mg}, 3: 0.13 \mathrm{mmol}, 2: 0.26 \mathrm{mmol})$ was dissolved in water $(12.0 \mathrm{~mL})$. To the solution was added $\alpha-C D(256.8 \mathrm{mg}, 0.26 \mathrm{mmol})$ and water $(10.0 \mathrm{~mL})$. The solution was heated for $102 \mathrm{~h}$ under reflux. The solution was cooled to room temperature, and the 
resulting solution was analyzed by NMR spectroscopy and TEM. NMR data were obtained from the equilibrated mixture of the rotaxane and starting materials. ${ }^{1} \mathrm{H}-\mathrm{NMR}\left(400 \mathrm{MHz}, \mathrm{D}_{2} \mathrm{O}\right.$, r.t.): $\delta 1.11-1.77$ $\left(\mathrm{m}, 16 \mathrm{H}, \mathrm{CH}_{2}\right.$ ), 1.70 (quin, $2 \mathrm{H}, \mathrm{OCH}_{2} \mathrm{CH}_{2}, J=5.2 \mathrm{~Hz}$ ), 2.16 (quin, $2 \mathrm{H}, \mathrm{NCH}_{2} \mathrm{CH}_{2}, J=6.1 \mathrm{~Hz}$ ), $2.58-3.14$ $\left(19 \mathrm{H}, \mathrm{NCH}_{3}, \mathrm{NCH}_{2}\right), 3.46-3.80\left(4 \mathrm{H}, \mathrm{NCH}_{2}\right), 3.56-3.74\left(\mathrm{~m}, 12 \mathrm{H}, \mathrm{C}_{36} \mathrm{H}_{72} \mathrm{O}_{36}-\mathrm{H} 4,-\mathrm{H} 2\right), 3.74-3.96(\mathrm{~m}, 12 \mathrm{H}$, $\left.\mathrm{C}_{36} \mathrm{H}_{72} \mathrm{O}_{36}-\mathrm{H} 6,-\mathrm{H} 5\right), 3.82$ (s, 6H, OCH $), 3.96-4.07$ (m, 6H, $\mathrm{C}_{36} \mathrm{H}_{72} \mathrm{O}_{36}-\mathrm{H} 3$ ), 4.04 (brs, 2H, OCH $), 4.75$ $\left(\mathrm{t}, 2 \mathrm{H}, \mathrm{NCH}_{2}, J=8.4 \mathrm{~Hz}\right), 5.05-5.11\left(\mathrm{~m}, 6 \mathrm{H}, \mathrm{C}_{36} \mathrm{H}_{72} \mathrm{O}_{36}-\mathrm{H} 1\right), 6.23\left(\mathrm{~s}, 2 \mathrm{H}, \mathrm{C}_{6} \mathrm{H}_{3}\right), 6.30\left(\mathrm{~s}, 1 \mathrm{H}, \mathrm{C}_{6} \mathrm{H}_{3}\right), 8.26$ $\left(\mathrm{d}, 2 \mathrm{H}, \mathrm{C}_{10} \mathrm{H}_{8} \mathrm{~N}_{2}, J=5.8 \mathrm{~Hz}\right), 8.48\left(\mathrm{~d}, 2 \mathrm{H}, \mathrm{C}_{10} \mathrm{H}_{8} \mathrm{~N}_{2}, J=6.3 \mathrm{~Hz}\right), 9.08\left(\mathrm{~d}, 2 \mathrm{H}, \mathrm{C}_{10} \mathrm{H}_{8} \mathrm{~N}_{2}, J=6.4 \mathrm{~Hz}\right)$, $9.19\left(\mathrm{~d}, 1 \mathrm{H}, \mathrm{C}_{10} \mathrm{H}_{8} \mathrm{~N}_{2}, J=6.1 \mathrm{~Hz}\right), 9.42\left(\mathrm{~d}, 1 \mathrm{H}, \mathrm{C}_{10} \mathrm{H}_{8} \mathrm{~N}_{2}, J=5.5 \mathrm{~Hz}\right)$. ESI-MS (eluent: $\left.\mathrm{H}_{2} \mathrm{O}\right)$ : calcd for $\left[\mathrm{C}_{75} \mathrm{H}_{124} \mathrm{~N}_{5} \mathrm{O}_{33} \mathrm{Pt}\right]^{2+}$ 606.26, found $606.26\left(\mathrm{M}^{2+}\right)$.

\subsection{Rotaxane of $\beta-\mathrm{CD}$ with $\left[\mathrm{Pt}\left(\mathrm{Me} e_{5}\right.\right.$ dien $)\left(4,4^{\prime}-\right.$ bpy-N- $\left.\left.\left.\left(\mathrm{CH}_{2}\right)_{12} \mathrm{OC}_{6} \mathrm{H}_{3}-3,5-(\mathrm{OMe})_{2}\right)\right]\left[\mathrm{NO}_{3}\right]_{3}\right)$}

A mixture of $[3]^{+}$and $[2]^{+}$in 1:2 molar ratio $(12.1 \mathrm{mg}, 3: 0.006 \mathrm{mmol}, 2: 0.012 \mathrm{mmol})$ was dissolved in water $(12.0 \mathrm{~mL})$. To the solution was added $\beta-\mathrm{CD}(6.8 \mathrm{mg}, 0.006 \mathrm{mmol})$ and water $(1.0 \mathrm{~mL})$. Stirring the solution for $5 \mathrm{~min}$ yielded a yellow solution. The solution was analyzed by NMR spectroscopy and TEM. NMR data were obtained from the equilibrated mixture of the rotaxane and starting materials. ${ }^{1} \mathrm{H}-\mathrm{NMR}\left(500 \mathrm{MHz}, \mathrm{D}_{2} \mathrm{O}\right.$, r.t.): $\delta 1.24-1.49\left(\mathrm{~m}, 16 \mathrm{H}, \mathrm{CH}_{2}\right), 1.69\left(\mathrm{~m}, 2 \mathrm{H}, \mathrm{OCH}_{2} \mathrm{CH}_{2}\right), 2.12(\mathrm{~m}, 2 \mathrm{H}$, $\left.\mathrm{NCH}_{2} \mathrm{CH}_{2}\right), 2.58-3.18\left(19 \mathrm{H}, \mathrm{NCH}_{3}, \mathrm{NCH}_{2}\right), 3.46-3.80\left(4 \mathrm{H}, \mathrm{NCH}_{2}\right), 3.59-3.73\left(\mathrm{~m}, 14 \mathrm{H}, \mathrm{C}_{42} \mathrm{H}_{84} \mathrm{O}_{42}-\mathrm{H}_{4}\right.$, -H2), 3.73-3.96 (m, 12H, $\left.\mathrm{C}_{42} \mathrm{H}_{84} \mathrm{O}_{42}-\mathrm{H} 6,-\mathrm{H} 5\right), 3.83\left(\mathrm{~s}, 6 \mathrm{H}, \mathrm{OCH}_{3}\right), 3.96-3.90\left(\mathrm{~m}, 6 \mathrm{H}, \mathrm{C}_{42} \mathrm{H}_{84} \mathrm{O}_{42}-\mathrm{H} 3\right)$, 4.01 (brs, 2H, OCH $)_{2}, 4.72\left(\mathrm{t}, 2 \mathrm{H}, \mathrm{NCH}_{2}, J=7.6 \mathrm{~Hz}\right), 5.05-5.11\left(\mathrm{~d}, 6 \mathrm{H}, \mathrm{C}_{36} \mathrm{H}_{72} \mathrm{O}_{36}-\mathrm{H} 1, J=3.6 \mathrm{~Hz}\right), 6.17$ $\left(\mathrm{s}, 2 \mathrm{H}, \mathrm{C}_{6} \mathrm{H}_{3}\right), 6.28\left(\mathrm{~s}, 1 \mathrm{H}, \mathrm{C}_{6} \mathrm{H}_{3}\right), 8.25$ (brs, $\left.2 \mathrm{H}, \mathrm{C}_{10} \mathrm{H}_{8} \mathrm{~N}_{2}, J=5.8 \mathrm{~Hz}\right), 8.48\left(\mathrm{~d}, 2 \mathrm{H}, \mathrm{C}_{10} \mathrm{H}_{8} \mathrm{~N}_{2}, J=6.0 \mathrm{~Hz}\right)$, $9.08\left(\mathrm{~d}, 2 \mathrm{H}, \mathrm{C}_{10} \mathrm{H}_{8} \mathrm{~N}_{2}, J=5.4 \mathrm{~Hz}\right), 9.18\left(\mathrm{~d}, 1 \mathrm{H}, \mathrm{C}_{10} \mathrm{H}_{8} \mathrm{~N}_{2}, J=6.3 \mathrm{~Hz}\right), 9.41\left(\mathrm{~d}, 1 \mathrm{H}, \mathrm{C}_{10} \mathrm{H}_{8} \mathrm{~N}_{2}, J=6.1 \mathrm{~Hz}\right)$.

\subsection{Rotaxane of $\gamma-\mathrm{CD}$ with $\left[\mathrm{Pt}\left(\mathrm{Me} e_{5}\right.\right.$ dien $\left.)\left(4,4^{\prime}-\mathrm{bpy}-\mathrm{N}-\left(\mathrm{CH}_{2}\right)_{12} \mathrm{OC}_{6} \mathrm{H}_{3}-3,5-(\mathrm{OMe})_{2}\right)\right]\left[\mathrm{NO}_{3}\right]_{3}$}

Preparation was conducted, similar to the rotaxane with $\beta$-CD. NMR data were obtained from the equilibrated mixture of the rotaxane and starting materials. ${ }^{1} \mathrm{H}-\mathrm{NMR}\left(500 \mathrm{MHz}, \mathrm{D}_{2} \mathrm{O}\right.$, r.t.): $\delta 1.02-1.39$ $\left(\mathrm{m}, 16 \mathrm{H}, \mathrm{CH}_{2}\right), 1.63\left(\mathrm{~m}, 2 \mathrm{H}, \mathrm{OCH}_{2} \mathrm{CH}_{2}\right), 2.04\left(\mathrm{~m}, 2 \mathrm{H}, \mathrm{NCH}_{2} \mathrm{CH}_{2}, J=7.4 \mathrm{~Hz}\right), 2.58-3.22\left(\mathrm{~m}, 19 \mathrm{H}, \mathrm{NCH}_{3}\right.$, $\left.\mathrm{NCH}_{2}\right), 3.59-3.70\left(\mathrm{~m}, 14 \mathrm{H}, \mathrm{C}_{48} \mathrm{H}_{96} \mathrm{O}_{48}-\mathrm{H} 4,-\mathrm{H} 2\right), 3.66\left(\mathrm{td}, 2 \mathrm{H}, \mathrm{NCH}_{2}, J=13.6,4.1 \mathrm{~Hz}\right), 3.70-3.77$ (m, $\left.12 \mathrm{H}, \mathrm{C}_{48} \mathrm{H}_{96} \mathrm{O}_{48}-\mathrm{H} 6,-\mathrm{H} 5\right), 3.86\left(\mathrm{td}, 2 \mathrm{H}, \mathrm{NCH}_{2}, J=12.7,3.0 \mathrm{~Hz}\right), 3.81\left(\mathrm{~s}, 6 \mathrm{H}, \mathrm{OCH}_{3}\right), 3.77-3.84(\mathrm{~m}, 6 \mathrm{H}$, $\mathrm{C}_{48} \mathrm{H}_{96} \mathrm{O}_{48}-\mathrm{H} 3$ ), 3.89 (brs, $\left.2 \mathrm{H}, \mathrm{OCH}_{2}\right), 4.67$ (t, 2H, $\left.\mathrm{NCH}_{2}, J=8.3 \mathrm{~Hz}\right), 5.09\left(\mathrm{~d}, 6 \mathrm{H}, \mathrm{C}_{48} \mathrm{H}_{96} \mathrm{O}_{48}-\mathrm{H} 1, J=\right.$ $3.7 \mathrm{~Hz}), 5.97\left(\mathrm{~s}, 2 \mathrm{H}, \mathrm{C}_{6} \mathrm{H}_{3}\right), 5.06\left(\mathrm{~s}, 1 \mathrm{H}, \mathrm{C}_{6} \mathrm{H}_{3}\right), 8.24$ (brs, $\left.2 \mathrm{H}, \mathrm{C}_{10} \mathrm{H}_{8} \mathrm{~N}_{2}\right), 8.49\left(\mathrm{~d}, 2 \mathrm{H}, \mathrm{C}_{10} \mathrm{H}_{8} \mathrm{~N}_{2}, J=6.6 \mathrm{~Hz}\right)$, $9.04\left(\mathrm{~d}, 2 \mathrm{H}, \mathrm{C}_{10} \mathrm{H}_{8} \mathrm{~N}_{2}, J=6.6 \mathrm{~Hz}\right), 9.18\left(\mathrm{~d}, 1 \mathrm{H}, \mathrm{C}_{10} \mathrm{H}_{8} \mathrm{~N}_{2}, J=6.4 \mathrm{~Hz}\right), 9.42\left(\mathrm{~d}, 1 \mathrm{H}, \mathrm{C}_{10} \mathrm{H}_{8} \mathrm{~N}_{2}, J=6.2 \mathrm{~Hz}\right)$.

\subsection{Reduction of Pt Complex and Its Rotaxanes}

A solution of [3] $\left(\mathrm{NO}_{3}\right)(0.1-12 \mu \mathrm{mol})$ in water $([3]=0.1-12.0 \mathrm{mM}, 1.0 \mathrm{~mL})$ was prepared. It was treated with a solution of $\mathrm{NaBH}_{4}$ (30 eq. to [3], 0.1-13.6 mg, 3.0-360 $\mu \mathrm{mol}$ ) in water (3.0-360 mM, $1.0 \mathrm{~mL}$ ). Stirring the mixture for $17 \mathrm{~h}$ at room temperature caused formation of a colorless to pale brown solution. A drop of the solution was transferred to the surface of carbon-coated $\mathrm{Cu}$ grids, and the resulting product was analyzed by TEM. Reduction of the rotaxanes to Pt nanoparticles was carried out analogously.

\section{Conclusions}

The Pt complex with a bipyridinium ligand having a long $N$-alkyl substituent forms rotaxanes with $\alpha-, \beta-$, and $\gamma$-cyclodextrins. These rotaxane aggregate in aqueous media to form micelles or vesicles, depending on the size of the cyclodextrins. The reduction of the $\mathrm{Pt}(\mathrm{II})$ complex and its rotaxanes by $\mathrm{NaBH}_{4}$ afforded Pt nanoparticles with regulated and small sizes (diameters of 1.3-2.8 nm). The Pt nanoparticles from the cyclodextrins are stable at $70{ }^{\circ} \mathrm{C}$, while those without $\mathrm{CDs}$ tended to aggregate in the solution. The protection of the resulting Pt particles by cyclodextrins and/or alkylbipyridnium functioned effectively to stabilize the nanoparticles. 
Author Contributions: Individual contributions of the authors are as follows. Conceptualization, Y.S. and Y.F.; investigation, Y.S., Y.F., and K.O.; writing-original draft preparation and editing, K.O.; funding acquisition, Y.S. and K.O. All authors have read and agreed to the published version of the manuscript.

Funding: This research was funded by Japan Society for Promotion of Science, grant number 25810059 and by Dynamic Alliance for Open Innovation Bridging from Ministry of Education, Culture, Sports, Science, and Technology-Japan.

Acknowledgments: We appreciate our colleagues in the Materials Analysis Division, Technical Department, Tokyo Institute of Technology.

Conflicts of Interest: The authors have no conflict of interest.

\section{References}

1. Chen, A.; Holt-Hindle, P. Platinum-Based Nanostructured Materials: Synthesis, Properties, and Applications. Chem. Rev. 2010, 110, 3767-3804. [CrossRef] [PubMed]

2. Sharma, R.K.; Sharma, P.; Maitra, A. Size-dependent Catalytic Behavior of Platinum Nanoparticles on the Hexacyanoferrate(III)/Thiosulfate Redox Solution. J. Colloid Interface Sci. 2003, 265, 134-140. [CrossRef]

3. Lee, H.; Habas, S.E.; Kweskin, S.; Bucher, D.; Somorjai, G.A.; Yang, P. Morphological Control of Catalytically Active Platinum Nanocrystals. Angew. Chem. Int. Ed. 2006, 45, 7824-7828. [CrossRef] [PubMed]

4. Wu, G.-W.; He, S.-B.; Peng, H.-P.; Deng, H.-H.; Liu, A.-L.; Lin, X.-H.; Xia, X.-H.; Chen, W. Citrate-Capped Platinum Nanoparticle as a Smart Probe for Ultrasensitive Mercury Sensing. Anal. Chem. 2014, 86, 10955-10960. [CrossRef]

5. Wang, Y.; Toshima, N. Preparation of Pd-Pt Bimetallic Colloids with Controllable Core/Shell Structures. J. Phys. Chem. B 1997, 101, 5301-5306. [CrossRef]

6. Shiraishi, Y.; Nakayama, M.; Takagi, E.; Tominaga, T.; Toshima, N. Effect of Quantity of Polymer on Catalysis and Superstructure Size of Polymer-protected Pt Nanoclusters. Inorg. Chim. Acta 2000, 300, 964-969. [CrossRef]

7. Luo, M.; Hong, Y.; Yao, W.; Huang, C.; Xu, Q.; Wu, Q. Facile Removal of Polyvinylpyrrolidone (PVP) Adsorbates from Pt Alloy Nanoparticles. J. Mater. Chem. A 2015, 3, 2770-2775. [CrossRef]

8. Zou, F.; Zhou, J.; Zhang, J.; Li, J.; Tang, B.; Chen, W.; Wang, J.; Wang, X. Functionalization of Silk with In-Situ Synthesized Platinum Nanoparticles. Materials 2018, 11, 1929. [CrossRef]

9. Watanabe, A.; Kajita, M.; Kim, J.; Kanayama, A.; Takahashi, K.; Mashino, T.; Miyamoto, Y. In Vitro Free Radical Scavenging Activity of Platinum Nanoparticles. Nanotechnology 2009, 20, 455105. [CrossRef]

10. Guo, G.; Qin, F.; Yang, D.; Wang, C.; Xu, H.; Yang, S. Synthesis of Platinum Nanoparticles Supported on Poly(acrylic acid) Grafted MWNTs and Their Hydrogenation of Citral. Chem. Mater. 2008, 20, 2291-2297. [CrossRef]

11. Witham, C.A.; Huang, W.; Tsung, C.K.; Kuhn, J.N.; Somorjai, G.A.; Toste, F.D. Converting Homogeneous to Heterogeneous in Electrophilic Catalysis Using Monodisperse Metal Nanoparticles. Nat. Chem. 2010, 2, 36-41. [CrossRef] [PubMed]

12. Schill, G. Catenanes, Rotaxanes, and Knots, 1st ed.; Aademic Press: New York, NY, USA, 1971.

13. Amabilino, D.B.; Stoddart, J.F. Interlocked and Intertwined Structures and Superstructures. Chem. Rev. 1995, 95, 2725-2828. [CrossRef]

14. Jäger, R.; Vögtle, F. A New Synthetic Strategy towards Molecules with Mechanical Bonds: Nonionic Template Synthesis of Amide-Linked Catenanes and Rotaxanes. Angew. Chem. Int. Ed. Engl. 1997, 36, 930-944. [CrossRef]

15. Chambron, J.-C.; Sauvage, J.P. Functional Rotaxanes: From Controlled Molecular Motions to Electron Transfer between Chemically Nonconnected Chromophores. Chem. A Eur. J. 1998, 4, 1362-1366. [CrossRef]

16. Hubin, T.J.; Busch, D.H. Template Routes to Interlocked Molecular Structures and Orderly Molecular Entanglements. Coord. Chem. Rev. 2000, 200, 5-52. [CrossRef]

17. Takata, T.; Kihara, N. Rotaxanes Synthesized from Crown Ethers and sec-Ammonium Salts. Rev. Heteroat. Chem. 2000, 22, 197-218. [CrossRef]

18. Erbas-Cakmak, S.; Leigh, D.A.; McTernan, C.T.; Nussbaumer, A.L. Artificial Molecular Machines. Chem. Rev. 2015, 115, 10081-10206. [CrossRef] 
19. Kim, K. Mechanically Interlocked Molecules Incorporating Cucurbituril and their Supramolecular Assemblies. Chem. Soc. Rev. 2002, 31, 96-107. [CrossRef]

20. Collin, J.-P.; Sauvage, J.-P. Transition Metal-complexed Catenanes and Rotaxanes as Light-driven Molecular Machines Prototypes. Chem. Lett. 2005, 34, 742-747. [CrossRef]

21. Leigh, D.A.; Marcos, V.; Wilson, M.R. Rotaxane Catalysts. ACS Catal. 2014, 4, 4490-4497. [CrossRef]

22. Thordarson, P.; Bijsterveld, E.J.A.; Rowan, A.E.; Nolte, R.J.M. Epoxidation of polybutadiene by a topologically linked catalyst. Nature 2003, 424, 915-918. [CrossRef]

23. Monnereau, C.; Ramos, P.H.; Deutman, A.B.C.; Elemans, J.A.A.W.; Nolte, R.J.M.; Rowan, A.E. Porphyrin Macrocyclic Catalysts for the Processive Oxidation of Polymer Substrates. J. Am. Chem. Soc. 2010, 132, 1529-1531. [CrossRef] [PubMed]

24. Hattori, G.; Hori, T.; Miyake, Y.; Nishibayashi, Y. Design and Preparation of a Chiral Ligand Based on a Pseudorotaxane Skeleton: Application to Rhodium-Catalyzed Enantioselective Hydrogenation of Enamides. J. Am. Chem. Soc. 2007, 129, 12930-12931. [CrossRef] [PubMed]

25. Suzaki, Y.; Shimada, K.; Chihara, E.; Saito, T.; Tsuchido, Y.; Osakada, K. [3]Rotaxane-Based Dinuclear Palladium Catalysts for Ring-closure Mizoroki-Heck Reaction. Org. Lett. 2011, 13, 3774-3777. [CrossRef] [PubMed]

26. Ogino, H. Relatively High-yield Syntheses of Rotaxanes. Syntheses and Properties of Compounds Consisting of Cyclodextrins Threaded by $\alpha, \omega$-Diaminoalkanes Coordinated to Cobalt(III) Complexes. J. Am. Chem. Soc. 1981, 103, 1303-1304. [CrossRef]

27. Ogino, H.; Ohata, K. Synthesis and Properties of Rotaxane Complexes. 2. Rotaxanes Consisting of $\alpha$ - or $\beta$-Cyclodextrin Threaded by ( $\mu$ - $\alpha, \omega$-diaminoalkane) bis [chlorobis (ethylenediamine) cobalt(III)] Complexes. Inorg. Chem. 1984, 23, 3312-3316. [CrossRef]

28. Wylie, R.S.; Macartney, D.H. Self-assembling Metal Rotaxane Complexes of $\alpha$-Cyclodextrin. J. Am. Chem. Soc. 1992, 114, 3136-3138. [CrossRef]

29. Wylie, R.S.; Macartney, D.H. The Self-assembly of $\alpha$-Cyclodextrin Rotaxanes of $\mu$-(1,1"'-( $\alpha, \omega$-Alkanediyl)bis-(4,4'-bipyridinium))bis[pentacyanoferrate-(II)] Complexes. Supramol. Chem. 1993, 3, 29-35. [CrossRef]

30. Macartney, D.H.; Waddling, C.A. Kinetic and Spectroscopic Studies on Pentacyano(N-heterocycle)ferrate(II) Rotaxanes of $\alpha$-Cyclodextrin with Symmetric and Asymmetric Threads. Inorg. Chem. 1994, 33, 5912-5919. [CrossRef]

31. Harada, A.; Li, J.; Kamachi, M. The Molecular Necklace: A Rotaxane Containing Many Threaded $\alpha$-Cyclodextrins. Nature 1992, 356, 325-327. [CrossRef]

32. Harada, A.; Li, J.; Kamachi, M. Synthesis of a Tubular Polymer from Threaded Cyclodextrins. Nature 1993, 364, 516-518. [CrossRef]

33. Harada, A. Preparation and Structures of Supramolecules between Cyclodextrins and Polymers. Coord. Chem. Rev. 1996, 148, 115-133. [CrossRef]

34. Harada, A. Cyclodextrin-Based Molecular Machines. Acc. Chem. Res. 2001, 34, 456-464. [CrossRef] [PubMed]

35. Nepogodiev, S.A.; Stoddart, J.F. Cyclodextrin-Based Catenanes and Rotaxanes. Chem. Rev. 1998, 98, $1959-1976$. [CrossRef]

36. Yamaguchi, I.; Osakada, K.; Yamamoto, T. Polyrotaxane Containing a Blocking Group in Every Structural Unit of the Polymer Chain. Direct Synthesis of Poly(alkylenebenzimidazole) Rotaxane from Ru Complex-Catalyzed Reaction of 1,12-Dodecanediol and 3,3'-Diaminobenzidine in the Presence of Cyclodextrin. J. Am. Chem. Soc. 1996, 118, 1811-1812. [CrossRef]

37. Yamaguchi, I.; Osakada, K.; Yamamoto, T. Introduction of a Long Alkyl Side Chain to Poly(benzimidazole)s. N-Alkylation of the Imidazole Ring and Synthesis of Novel Side Chain Polyrotaxanes. Macromolecules 1997, 30, 4288-4294. [CrossRef]

38. Yamaguchi, I.; Takenaka, Y.; Osakada, K.; Yamamoto, T. Preparation and Characterization of Polyurethane-Cyclodextrin Pseudopolyrotaxanes. Macromolecules 1999, 32, 2051-2054. [CrossRef]

39. Yamaguchi, I.; Osakada, K.; Yamamoto, T. Pseudopolyrotaxane Composed of an Azobenzenepolymer and $\gamma$-Cyclodextrin. Reversible and Irreversible Photoisomerization of the Aazobenzene Groups in the Polymer Chain. Chem. Commun. 2000, 14, 1335-1336. [CrossRef] 
40. Suzaki, Y.; Taira, T.; Osakada, K.; Horie, M. Rotaxanes and Pseudorotaxanes with Fe-, Pd- and Pt-containing Axles. Molecular Motion in the Solid State and Aggregation in Solution. Dalton Trans. 2008, 4823-4833. [CrossRef]

41. Suzaki, Y.; Taira, T.; Osakada, K. Irreversible and Reversible Formation of a [2]Rotaxane Containing Platinum(ii) Complex with an N-Alkyl Bipyridinium Ligand as the Axis Component. Dalton Trans. 2006, 5345-5351. [CrossRef]

42. Taira, T.; Suzaki, Y.; Osakada, K. [5]Rotaxanes Composed of $\alpha$-Cyclodextrin and Pd or Pt Complexes with Alkylbipyridinium Ligands. Chem. Lett. 2008, 37, 182-183. [CrossRef]

43. Taira, T.; Suzaki, Y.; Osakada, K. PdII and PtII Complexes with Amphiphilic Ligands: Formation of Micelles and [5]Rotaxanes with $\alpha$-Cyclodextrin in Aqueous Solution. Chem. Asian J. 2008, 3, 895-902. [CrossRef] [PubMed]

44. Endo, H.; Suzaki, Y.; Komura, M.; Osakada, K. Bi- and Multilayered Assembly of Amphiphilic Pd(II) and Pt(II) Complexes with N-Alkyl-4,4'-bipyridinium Ligands. Bull. Chem. Soc. Jpn. 2016, 89, 1069-1071. [CrossRef]

45. Lee, C.-L.; Ju, Y.-C.; Chou, P.-T.; Huang, Y.-C.; Kuo, L.-C.; Oung, J.-C. Preparation of Pt Nanoparticles on Carbon Nanotubes and Graphite Nanofibers via Self-regulated Reduction of Surfactants and their Application as Electrochemical Catalyst. Electrochem. Commun. 2005, 7, 453-458. [CrossRef]

46. Zaluzhna, O.; Li, Y.; Allison, T.C.; Tong, Y.J. Inverse-Micelle-Encapsulated Water-Enabled Bond Breaking of Dialkyl Diselenide/Disulfide: A Critical Step for Synthesizing High-Quality Gold Nanoparticles. J. Am. Chem. Soc. 2012, 134, 17991-17996. [CrossRef] [PubMed]

47. Chaudhary, G.R.; Singh, P.; Kaur, G.; Mehta, S.K.; Kumar, S.; Dilbaghi, N. Multifaceted Approach for the Fabrication of Metallomicelles and Metallic Nanoparticles Using Solvophobic Bisdodecylaminepalladium (II) Chloride as Precursor. Inorg. Chem. 2015, 54, 9002-9012. [CrossRef] [PubMed]

48. Alvarev, J.; Liu, J.; Román, E.; Kaifer, A.E. Water-soluble Platinum and Palladium Nanoparticles Modified with Thiolated $\beta$-Cyclodextrin. Chem. Commun. 2000, 1151-1152. [CrossRef]

49. Strimbu, L.; Liu, J.; Kaifer, A.E. Cyclodextrin-Capped Palladium Nanoparticles as Catalysts for the Suzuki Reaction. Langmuir 2003, 19, 483-485. [CrossRef]

50. Li, Z.; Zhang, L.; Huang, X.; Ye, L.; Lin, S. Shape-Controlled Synthesis of Pt Nanoparticles via Integration of Graphene and $\beta$-Cyclodextrin and Using as a Novel Electrocatalyst for Methanol Oxidation. Electrochim. Acta 2014, 121, 215-222. [CrossRef]

Publisher's Note: MDPI stays neutral with regard to jurisdictional claims in published maps and institutional affiliations.

(C) 2020 by the authors. Licensee MDPI, Basel, Switzerland. This article is an open access article distributed under the terms and conditions of the Creative Commons Attribution (CC BY) license (http://creativecommons.org/licenses/by/4.0/). 